\title{
Organized Pseudolegal Commercial Arguments as Magic and Ceremony
}

\author{
DONALD J. NETOLITZKY*
}

\begin{abstract}
This article discusses ways in which Organized Pseudolegal Commercial Arguments (OPCA) litigants use pseudolegal concepts, techniques, and procedures before the courts. The author begins by looking at where OPCA legal arguments originate, and the historical sources where these arguments find grounding, while assessing the flaws in such. A thorough analysis is then conducted into some of the tactics used by OPCA litigants in order to evade legal consequences, including a survey of global case law where these arguments have been brought before the courts. The article culminates with an analysis of the implications of the use of pseudolaw by OPCA litigants and how tactics permeate through OPCA movements, while looking for solutions in dealing with OPCA litigants as they move through the courts.
\end{abstract}

\section{TABLE OF CONTENTS}

I. INTRODUCTION . . . . . . . . . . . . . . . . . . . . . . . . . . . . . . . . . . 1045

II. PSEUdOLAW AS LEGAL ERROR . . . . . . . . . . . . . . . . . . . . . . . . . . . . 1049

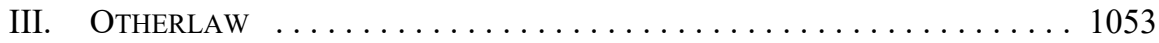

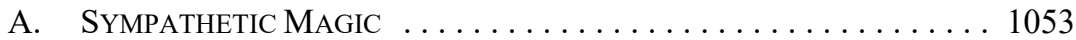

B. Cargo Cult law . . . . . . . . . . . . . . . . . . . 1057

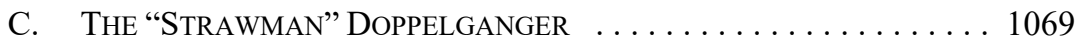

IV. IMPLICATIONS . . . . . . . . . . . . . . . . . . . . . . . . . 1079

A. Belief in Otherlaw is Not Universal . . . . . . . . . . . . . . . . . . . . . . . . . . . . . . . . . .

B. What Makes Otherlaw Acceptable? . . . . . . . . . . . . . 1080

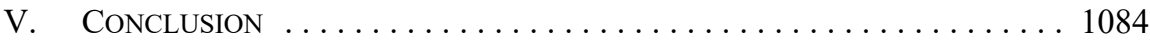

\section{INTRODUCTION}

Government, law enforcement, and courts in many Commonwealth countries now regularly encounter persons who claim extraordinary authority and immunity. While these claims are purportedly expressions of legal rights and principles, this "law" is not drawn from recognized sources. Instead, these are an alternative, different set of rules that mimic or ape the structure and language of "conventional" law. This variant law is a "pseudolaw." It superficially appears to be law, or related to law, but is otherwise spurious.

This phenomenon goes under different names in various jurisdictions. In the United States these ideas were incubated in a succession of right-wing, often racist, and predominately rural political groups: the Posse Comitatus, ${ }^{1}$ Christian Identity churches, ${ }^{2}$ Tax Protestors, ${ }^{3}$

Donald J Netolitzky, PhD Microbiology, University of Alberta, 1995; LLB, University of Alberta, 2005; Complex Litigant Management Counsel for the Alberta Court of Queen's Bench. The views expressed in this article are those of the author, and not those of any other member of the Court of Queen's Bench, or the Court itself.

1 James Corcoran, Bitter Harvest: Gordon Kahl and the Posse Comitatus: Murder in the Heartland (New York: Viking, 1990).

2 Michael Barkun, Religion and the Racist Right: The Origins of the Christian Identity Movement (Chapel Hill: The University of North Carolina Press, 1994) [Barkun, Christian Identity].

3 Christopher S Jackson, "The Inane Gospel of Tax Protest: Resist Rendering Unto Caesar — Whatever His Demands" (1996) 32:2 Gonz L Rev 291. 
Militias, ${ }^{4}$ and the Sovereign Citizen movement. Unexpectedly, after 2000 much the same set of pseudolaw translocated to ideologically alien environments, including:

1. urban United States black populations, who self-identify as Moors or Aboriginal peoples, and claim immunity or special status on the basis of race $;^{5}$ and

2. Freemen-on-the-Land, ${ }^{6}$ a collection of Canadian, politically leftist, "Green," antiglobalization, marijuana advocacy, and anti-government social activists who "opt out" of government control.

Canadian and US pseudolegal concepts have subsequently spread to other countries in the Commonwealth (United Kingdom, Scotland, Republic of Ireland, Northern Ireland, Australia, New Zealand, South Africa), and also taken root in other more unlikely places (Norway, the Netherlands, Austria, Germany). Curiously, pseudolaw's content and language has remained unexpectedly constant as it has spread.

American legal academics have been writing about pseudolaw and its implications for decades, largely in the context of these ideas as risk factors. ${ }^{7}$ In Canada, pseudolaw only recently became a subject of systematic investigation and commentary, though it has a long history in this country. A major step was an Alberta Court of Queen's Bench judgment, Meads v. Meads, ${ }^{8}$ which reviewed close to 150 decisions that involved pseudolaw, organized and classified pseudolegal concepts, described communities that host pseudolaw, and identified pseudolaw promoters or "gurus." These schemes were grouped under a single name: Organized Pseudolegal Commercial Arguments (OPCA). Other US and German court

Morris Dees \& James Corcoran, Gathering Storm: America's Militia Threat (New York: HarperCollins, 1996); David A Neiwert, In God's Country: The Patriot Movement and the Pacific Northwest (Pullman: Washington State University Press, 1999); Robert L Snow, Terrorists Among Us: The Militia Threat (Cambridge, Mass: Perseus Publishing, 1999); Catherine Wessinger, How the Millennium Comes Violently: From Jonestown to Heaven's Gate (New York: Seven Bridges Press, 2000); Kenneth S Stern, A Force Upon the Plain: The American Militia Movement and the Politics of Hate (New York: Simon \& Schuster, 1996).

$5 \quad$ Kaitlyn Compari, “The Moorish Science Temple of America and the Legal System: Exploring the Need to Take Proactive Measures Against Radical Members of an Incorporated Religion" (2014) 15:3 Rutgers JL \& Religion 507; Spencer Dew, "Washitaw de Dugdahmoundyah: Counterfactual Religious Readings of the Law" (2015) 19:2 Nova Religio 65; Spencer Dew, "Moors Know the Law': Sovereign Legal Discourse in Moorish Science Religious Communities and the Hermeneutics of Supersession" (2016) 31:1 JL \& Religion 70 [Dew, "Moors Know"]; Bill Osinski, Ungodly: A True Story of Unprecedented Evil (Macon, Ga: Indigo Custom Publishing, 2007); Susan Palmer, The Nuwaubian Nation: Black Spirituality and State Control (New York: Routledge, 2016).

Donald J Netolitzky, "The History of the Organized Pseudolegal Commercial Argument Phenomenon in Canada" (2016) 53:3 Alta L Rev 609 at 624-27 [Netolitzky, "OPCA History"]; Barbara Perry, David C Hofmann \& Ryan Scrivens, "Broadening our Understanding of Anti-Authority Movements in Canada" (2017) University of Waterloo TSAS Working Paper No 17-02.

See e.g. Angela P Harris, "Vultures in Eagles' Clothing: Conspiracy and Racial Fantasy in Populist Legal Thought" (2005) 10:2 Mich J Race \& L 269; Susan P Koniak, "The Chosen People in our Wilderness" (1997) 95:6 Mich L Rev 1761 [Koniak, "Chosen People"]; Susan P Koniak, "When Law Risks Madness" (1996) 8 Cardozo Stud L \& Lit 65 [Koniak, "Law Risks"]; Francis X Sullivan, "The 'Usurping Octopus of Jurisdictional/Authority': The Legal Theories of the Sovereign Citizen Movement" (1999) Wis L Rev 785; James M Vaché \& Mark Edward DeForrest, "Truth or Consequences: The Jurisprudential Errors of the Militant Far-Right" (1997) 32:3 Gonz L Rev 593; Mark Edward DeForrest \& James M Vaché, "Truth or Consequences Part Two: More Jurisprudential Errors of the Militant Far-Right" (2000) 35:3 Gonz L Rev 319. 2012 ABQB 571, [2013] 3 WWR 419 [Meads]. 
decisions have conducted similar broad surveys of their Sovereign Citizen, Moorish, ${ }^{9}$ and Reichsbürger phenomena. ${ }^{10}$

Post-Meads, appreciation of the social significance and illegal consequences of pseudolaw has led to academic investigation, a growing collection of highly detailed and responsive case law, ${ }^{11}$ and increased public awareness of the curious fact that there exist people who claim to operate under a different, and sometimes very different, set of rules. Reviews of OPCA history, activities, and suggested responses have been published in Canada, ${ }^{12} \mathrm{New}$ Zealand, ${ }^{13}$ and the Republic of Ireland. ${ }^{14}$ Mental health professionals have concluded that OPCA affiliation does not represent disordered thought, but instead is a distinct form of atypical political belief reinforced in marginal communities. ${ }^{15}$ Social scientists have investigated what factors foster OPCA beliefs, ${ }^{16}$ and the functional parallels between OPCA communities and religious cults. ${ }^{17}$ OPCA beliefs are a risk indicium, since OPCA gurus not only teach that individuals have a right to retaliate against uncooperative state, law enforcement, and court actors, but also because the populations which host these ideas generally identify government as an enemy, even an evil enemy, and therefore a target for (allegedly) justified retaliation and discipline. ${ }^{18}$

United States v Phillips, 2014 WL 4628588 (ND Ill); Marrakush Society v New Jersey State Police, 2009 WL 2366132 (NJ).

10 FG Münster No 14 (14 April 2015), Az 1 K 3123/14 F, online: <https://openjur.de/u/853611.html>. German researchers have produced impressive resources that document the Reichsbürgers, including Jan Rathje, Die "Reichsbürger": Überzeugungen, Gefahren und Handlungsstrategien (Berlin: Amadeu Antonio Stiftung, 2014) and Dirk Wilking, "Reichsbürger": Ein Handbuch (Potsdam: Brandenburgische Universitätsdruckerei und Verlagsgesellschaft Potsdam mbh, 2015).

11 See e.g. Fearn v Canada Customs, 2014 ABQB 114, 586 AR 23 [Fearn]; Bank of Montreal v Rogozinsky, 2014 ABQB 771, 603 AR 261 [Rogozinsky]; Servus Credit Union Ltd v Parlee, 2015 ABQB 700, 2015 ABQB 700 (CanLII) [Servus]; Crossroads-DMD Mortgage Investment Corporation $v$ Gauthier, 2015 ABQB 703, 60 RPR (5th) 28 [Crossroads]; Fiander v Mills, 2015 NLCA 31, 368 Nfld \& PEIR 80 [Fiander]; Bossé v Farm Credit Canada, 2014 NBCA 34, 419 NBR (2d) 1, leave to appeal to SCC refused, 36026 (11 December 2014) [Bossé]; Pomerleau v Canada (Revenue Agency), 2017 ABQB 123, [2017] 4 CTC 81 [Pomerleau].

12 Netolitzky, "OPCA History," supra note 6; Jason K Yamashita, "Utility Dealings with Freemen-on-theLand and Others Raising "Organized Pseudo-Legal Commercial Arguments"” (2015) 3:2 Energy Regulation Q 51; Donald J Netolitzky \& John D Rooke, "Organized Pseudolegal Commercial Argument [OPCA] Litigants: New Challenges in the Internet Age" (Paper delivered at the CIAJ National Roundtable on the Vexatious Litigant, Toronto, 10 March 2016) [unpublished]; Perry, Hofmann \& Scrivens, supra note 6; Donald J Netolitzky, "Lawyers and Court Representation of Organized Pseudolegal Commercial Argument [OPCA] Litigants in Canada" (2018) 51:2 UBC L Rev (in press) [Netolitzky, "Lawyers and OPCA"].

13 Thomas Bloy, "Pseudo-law and Debt Enforcement" (2013) 2 NZLJ 47.

14 Tomás Keys, "Freeman on the Land and Other Organized Lay Litigant Groups — Part 1" (2014) 10 Commercial L Practitioner 230; Tomás Keys, "Freeman on the Land and Other Organized Lay Litigant Groups - Part 2" (2014) 11 Commercial L Practitioner 256; Garret Sammon, "'Organized PseudoLegal Commercial Argument' Litigation: Challenges for the Administration of Justice in Ireland" (2015) 38:1 Dublin ULJ 85; Niamh Barry \& Macdara O Drisceoil, "Constitutional Right to Protest and the Freemen on the Land Movement" (2017) 17:1 Irish Judicial Studies J 40.

15 Jennifer Pytyck \& Gary A Chaimowitz, "The Sovereign Citizen Movement and Fitness to Stand Trial" (2013) 12:2 Intl J Forensic Mental Health 149; George F Parker, "Competence to Stand Trial Evaluations of Sovereign Citizens: A Case Series and Primer of Odd Political and Legal Beliefs" (2014) 42:3 J American Academy Psychiatry \& L 338.

16 Stephen A Kent, "Freemen, Sovereign Citizens, and the Challenge to Public Order in British Heritage Countries" (2015) 6 Intl J Cultic Studies 1.

17 Stephen A Kent \& Robin D Willey, "Sects, Cults, and the Attack on Jurisprudence" (2013) 14:2 Rutgers JL \& Religion 306.

18 Donald J Netolitzky, "Organized Pseudolegal Commercial Arguments [OPCA] in Canada; an Attack on the Legal System" (2016) 10 JPPL 137 [Netolitzky, "Attack"]; Perry, Hofmann \& Scrivens, supra note 6 . 
Though OPCA schemes have emerged in a very wide variety of legal disputes, OPCA litigation is "clustered" in time, location, and subject. ${ }^{19}$ Most reported Canadian judgments involve OPCA arguments:

1. To avoid income tax, or evade criminal sanction for not paying income tax;

2. to subvert the legal basis for debts, or to pay a debt with "money for nothing" schemes;

3. as a "get out of jail free" card by criminal accused or offenders; or

4. in "offensive" lawsuits where OPCA litigants on a vexatious and abusive basis advance spurious claims against other parties. ${ }^{20}$

These objectives are consistent with the pattern that pseudolaw has, thus far, been largely contained in communities that are in conflict with or hostile to government and corporate authority. These groups typically hold profoundly conspiratorial beliefs ${ }^{21}$ concerning the nature and illegitimacy of "conventional" authorities, and are clearly attracted to the idea of another "true" hidden law that can be accessed to escape from or retaliate against those who are perceived as enemies or wrongdoers.

This article has a different focus from prior investigations. It excavates the foundation of pseudolegal concepts, techniques, and procedures. OPCA pseudolaw confuses legal professionals. For example, Commonwealth judgments which respond to OPCA concepts often describe these ideas as impenetrable, gibberish, or nonsense:

[U]nintelligible and incomprehensible at best and at worst as complete nonsense and a waste of this Court's resources and time. ${ }^{22}$

[A] waste of court, legal and judicial resources attempting to sift through the quagmire ... unintelligible and indecipherable. $^{23}$

[The defence and counterclaim were] comprised of random, almost incomprehensible, statements, propositions, quotations, argument and references to other material that appeared to have been lifted from other documents and randomly pasted into the pleading. ${ }^{24}$

Other judges have at least heard literary echoes hidden inside the unusual language found in OPCA documents: to Lewis Carroll's invented word poem "Jabberwocky," 25 and the stream of consciousness writing of Jack Kerouac. ${ }^{26}$ Lawyers describe OPCA documents as gibberish, "word salad," incomprehensible, and gobbledygook.

Netolitzky, “OPCA History,” supra note 6 at 611.

Donald J Netolitzky, "Organized Pseudolegal Commercial Arguments in Canadian Inter-Partner Family Law Court Disputes" (2017) 54:4 Alta L Rev 955 at 957-58 [Netolitzky, "OPCA in Family Law"]. See ibid at 957-59; Netolitzky, "OPCA History," supra note 6 at 635-36; Netolitzky, "Attack," supra note 18 at $138,143-45$.

Brown v R, 2014 TCC 91, 2014 DTC 1107 at para 7, rev'd in part 2014 FCA 301, 466 NR 160 [Brown]. Harper $v$ Bennet, 2015 SKQB 314, 2015 SKQB 314 (CanLII) at paras 23-24.

National Australia Bank Limited v Norman, [2012] VSC 14 at para 4.

$R v$ Bydeley, 2012 ONCJ 837, 2012 ONCJ 837 (CanLII) at para 18.

Kosteska v Magistrate Manthey \& Anor, [2013] QCA 105 at para 19. 
But why are OPCA concepts, documents, and arguments gobbledygook? And perhaps as importantly, are they always gobbledygook?

That is the subject of this investigation. This analysis cannot be comprehensive due to the broad scope and variety of known OPCA litigation, and the many variations that exist for common OPCA motifs and concepts. Instead, this article asks whether pseudolaw has a scheme.

This is a position advanced by US legal scholar Susan P. Koniak, who warns the legal establishment that voices in the Sovereign Citizen world are building their own distinct and separate schema of law $^{27}$. In certain senses Koniak is correct, but the answer, as it often is, is not so simple. Some OPCA misconceptions can be distilled into a discrete legal error. In those instances, pseudolaw takes an alternative path from "conventional" law, and thus, reaches a different result. These forks in the law are not always incomprehensible, so much as they are simply wrong, at least from the perspective of conventional authorities and the courts. A court or legal professional can explicitly and clearly respond to this category of pseudolaw. However, some OPCA pseudolaw, "Otherlaw," is entirely disconnected from "mainstream" law, and represents a "something else" category of thought, belief, and behaviour. $^{28}$

Magic is the best analogue for Otherlaw. Otherlaw has no reasoned foundation. In fact, certain examples have no foundation at all!

This does not mean, however, that there are not patterns to pseudolaw, including Otherlaw. Understanding these patterns is a potential conduit for a dialogue with those who advance these concepts. Put another way, pseudolaw provides a window into the psyche of OPCA affiliates and their world.

And soon we realize, like Dorothy, that "I've a feeling we're not in Kansas anymore."29

\section{Pseudolaw as Legal ERror}

Some pseudolaw is clearly based on legal error. Gurus are simply wrong when they teach what is allegedly a principle of law. An interesting feature common to pseudolegal errors is that OPCA gurus support these misconceptions with references to some kind of genuine legal text or resource. Legal errors emerge from what might appear as a potentially legitimate context.

A cornerstone legal error for many OPCA theories is that silence means consent or agreement. This misconception is typically framed as a principle of contract law, and places

Koniak, "Chosen People," supra note 7.

See Netolitzky, "OPCA History," supra note 6 at 637-39.

From the 1939 film, "The Wizard of Oz." This movie and the L Frank Baum novel The Wonderful Wizard of Oz (Chicago: George M Hill Company, 1900) has special status in OPCA circles, particularly the US Sovereign Citizen movement. It purportedly contains hidden and encoded information. For example, the popular "Accepted for Value" ("A4V") Redemption Manual, 5th ed, vol 1 (Lexington: Sovereign Filing Solutions, 2014) at 31-38 [Redemption Manual 5] highlights a concealed subtext, such as the "Tinman" actually means "Taxpayer Identification Number MAN." The motion picture "The Matrix" is viewed in a similar fashion (ibid at 39-67). 
a positive obligation on the recipient of a contract offer to reject that offer, otherwise the offer is deemed accepted and in force. This pseudolegal principle is the basis for a number of OPCA schemes, including:

1. The Freeman-on-the-Land "Notice of Understanding, Intent, and Claim of Right," which is a unilateral declaration that the writer has successfully "opted out" of legislation, unless rebutted;

2. "fee schedules," 31 which define a scheme of fines or payments that the recipient allegedly accepts by receipt without protest; fee schedules typically create fines for lawful conduct, such as a peace officer may be fined $\$ 10,000.00$ for stopping an OPCA affiliate's vehicle; and

3. the "Three/Five Letters" 32 scheme of debt elimination, where a failure to provide certain evidence allegedly negates the obligation to repay a debt.

This is, of course, incorrect. In law silence does not mean consent, and a contract cannot be "foisted" on a target. ${ }^{33}$ The need for this principle is obvious. We would otherwise be surrounded by potentially binding legal agreements that one would need to identify and rebut via unending vigilance.

Then why is this concept plausible to potential OPCA customers? One explanation is that OPCA affiliates see what they perceive as foisted unilateral agreements in their day-to-day lives, for example via "shrink wrap" software contracts, or banks changing the terms of a credit card service. OPCA gurus also point to court rules that require a party dispute allegations of fact. ${ }^{34}$

However, this "what is good for the goose is good for the gander" reasoning is not the only rationale for the "silence means consent or agreement" concept. Gurus cite a legal maxim, "Qui non negat fatetur," or "He who does not deny, admits" from Black's Law Dictionary. ${ }^{35}$ Other obsolete legal references provide similar, or even more compelling variations:

See Netolitzky, "Attack," supra note 18 at 150-51; Robert-Arthur Menard, With Lawful Excuse (Elizabeth Anne Elaine Society and Freddie Freepickle Productions, 2011) at 141-43.

31 Meads, supra note 8 at paras 505-23. Fee schedules are presumptively a form of intimidation: ibid at para 527; Rogozinsky, supra note 11 at para 78; Gidda $v$ Hirsch, 2014 BCSC 1286, 2014 BCSC 1286 (CanLII) at para 84; Re Boisjoli, 2015 ABQB 629, 29 Alta LR (6th) 334 at paras 58-67 [Boisjoli]; Gauthier $v$ Starr, 2016 ABQB 213, 86 CPC (7th) 348 at para 39; Pomerleau, supra note 11 at paras 133-36; Allen Boisjoli Holdings v Papadoptu, 2016 FC 1260, 2016 FC 1260 (CanLII) at para 17; Re Gauthier, 2017 ABQB 555, 2017 ABQB 555 (CanLII) at paras 64-69 [Re Gauthier], leave to appeal to ABCA refused, 2018 ABCA 14, 2018 ABCA 14 (CanLII).

32 Also known as a "Notary Protest" or an "Administrative Process." This scheme is reviewed in Rogozinsky, supra note 11 at paras 55-73; Rothweiler v Payette, 2018 ABQB 288, 2018 ABQB 288 (CanLII) at paras 6-21. The Three/Five Letters scheme is usually used for debt elimination, but this adaptable concept allegedly can prove liability (Boisjoli, ibid; Perreal v Knibb, 2014 ABQB 15, 581 AR 275 [Perreal]); defeat legislation (Robert Arthur Menard, Bursting Bubbles of Government Deception (Vancouver: Elizabeth Anne Elaine Society and Freddy Freepickle Productions, 2004) at 19-20; Menard, supra note 30 at 114, 144-53,167); and even obtain sexual consent from minors ( $R \vee T L P$, 2015 BCSC 618, 2015 BCSC 618 (CanLII), declared long term offender 2017 BCSC 1868, 2017 BCSC 1868 (CanLII).

33 Felthouse $v$ Bindley (1862), 142 ER 1037 (Ch), generally reviewed in Meads, supra note 8 at paras $458-72$.

34 For example, the "notice to admit" procedure: Alberta, Rules of Court, Alta Reg 124/2010, s 6.37.

35 Black's Law Dictionary, 4th ed, sub verbo "qui non negat fatetur." 
Qui non negat, fatetur. He who does not deny, admits. Trayner, Max. $503 .^{36}$

Qui non negat, fatetur. Lat. — "He who does not deny, virtually confesses." — "Silence gives assent.",37

1996. He who does not deny, confesses.

QUI NON NEGAT, FATETUR ${ }^{38}$

This, of course, is not the law. What then is the origin of this "maxim"? A closer look at the Black's Law Dictionary variation provides the explanation, as the full quotation is:

QUI NON NEGAT FATETUR. He who does not deny, admits. A well-known rule of pleading. Tray. Lat. Max. 503. ${ }^{39}$

This omitted element explains the disconnection. The Qui non negat fatetur rule has nothing to do with contracts, but instead guides how a court should interpret lawsuit pleadings, such as a statement of defence. The maxim is not false, but has been misapplied.

However, further dissection of the pithy phrases that allegedly provide the foundation for pseudolaw unearths stranger artifacts that allegedly form the legal foundation of the "silence means consent or agreement" rule. One is the "maxim" "[a]n unrebutted Affidavit is truth in Commerce." 40 That rule allegedly puts a positive obligation on the recipient of an affidavit to refute any content, which otherwise is proven to be true. This "maxim" is not found in the historic legal texts and dictionaries commonly referenced by OPCA gurus, nor any case law, but any Internet search reveals numerous OPCA resources which repeat this phrase. What is its origin? One hint is that some versions of this "maxim" are followed with text that appears to identify Bible passages. Sure enough, what appears to be the original form of this "maxim" is found in a list, "Maxims of Law: There are 10 essential maxims or precepts in commercial law," 41 which explicitly identifies Bible passages that establish so-called commercial law principles. ${ }^{42}$ The "unrebutted affidavit" rule is the fifth so-called maxim:

\section{AN UNREBUTTED AFFIDAVIT STANDS AS TRUTH IN COMMERCE.}

1 Pet. 1:25 But the word of the Lord endureth for ever. And this is the word which by the gospel is preached unto you;

Heb. 6:13-15 For when God made promise to Abraham, because he could swear by no greater, he sware by himself, Saying, Surely blessing I will bless thee, and multiplying I will multiply thee. And so after he had patiently endured he obtained the promise;

36 Bouvier's Law Dictionary, 15th ed, sub verbo "qui non negat fatetur."

37 A Dictionary of Select and Popular Quotations, Which Are in Daily Use: Taken from the Latin, French, Greek, Spanish, and Italian Languages: Together with a Copious Collection of Law-Maxims and LawTerms, 6th ed (Philadelphia: Lippincott, Grambo, \& Co, 1852) at 231.

38 James Appleton Morgan, An English Version of Legal Maxims, 3rd ed (Cincinnati: Robert Clarke \& Co, 1878 ) at 246.

39 Black's Law Dictionary, supra note 35 [emphasis added].

$40 \quad$ See Perreal, supra note 32, Schedule A; Dempsey v Envision Credit Union, 2006 BCSC 1324, 60 BCLR (4th) 309 at para 35; $R v$ Pinno, 2002 SKPC 118, [2003] 3 CTC 308 at para 22; $R v$ Boxrud, 2014 SKQB 221, 450 Sask R 147 at paras 1, 9; Boisjoli, supra note 31 at para 119.

41 Larry Hannigan, “03-Maxims of Law and the Nature of Law,"Larry: Hannigan (blog), online: $<$ https:// larryhannigan.com/courts/maxims-of-law-and-the-nature-of-law/>.

42 OPCA affiliates typically identify the King James Bible as the authoritative version: Meads, supra note 8 at paras $134-39,183-85,294,299,480-81,617$. 
Claims made in your affidavit, if not rebutted, emerge as the truth of the matter. Legal Maxim: "He who does not deny, admits." 43

Though conventional legal theory obviously rejects the Bible as a source for binding legal principles, ${ }^{44}$ the author of the "Maxims of Law" document also references the plausibly sourced "He who does not deny, admits." maxim as well. ${ }^{45}$ The exact origin of this particular motif is not obvious, but possibly dates to around 1970-1980 when the Christian Identity movement developed a codified scheme of Christian Common Law derived from biblical texts. $^{46}$

This is only one of many OPCA concepts that are plausibly anchored to actual legal references. Legal maxims are a common and attractive foundation, since gurus can readily cite historical authorities to argue these brief restatements are immutable rules of law. For example, the second edition of Black's Law Dictionary defines "maxim" as "[a]n established principle or proposition. A principle of law universally admitted, as being a correct statement of the law, or as agreeable to natural reason." ${ }^{\prime 7}$ Sir Edward Coke is often identified as the authoritative source for legal maxims. OPCA gurus collect and publish maxims as irrefutable principles. $^{48}$

Legal dictionaries are another useful resource, particularly since court judgments reference dictionaries as tools in legal analysis. ${ }^{49}$ Genuine case law is also used, but is typically misquoted, quoted in part, or out of context. ${ }^{50}$ Obscure legislation, such as the "consumer purchase" provisions of the Bills of Exchange Act, ${ }^{51}$ is another basis for legitimate-sounding OPCA schemes, as is bad legislative drafting.

The preamble to the Canadian Charter of Rights and Freedoms is a particularly obnoxious example of the latter, as it reads: "Whereas Canada is founded upon principles that recognize the supremacy of God and the rule of law." ${ }^{.52}$ Unsurprisingly, OPCA theorists have homed in on the "supremacy of God" language. While Canadian courts have concluded that phrase has minimal, if any, interpretative value, ${ }^{53}$ that has not stopped OPCA gurus from, very plausibly, arguing "the supremacy of God" in Canada's keystone statement of legal

$43 \quad$ Hannigan, supra note 41.

Meads, supra note 8 at paras 276-85.

Hannigan, supra note 41.

Barkun, Christian Identity, supra note 2 at 200-205. This effort focused on economic relations and principles.

47 Black's Law Dictionary, 2nd ed, sub verbo "maxim."

48 See e.g. Charles A Weisman, Maxims of Law (Apple Valley, Minn: Weisman Publications, 1990); Robert Arthur Menard, Letters to Authorities (Vancouver: Elizabeth Anne Elaine Society, 2003). These compilations include both genuine and questionable maxims.

49 See Dew, "Moors Know," supra note 5 at 84-87 for dictionaries in a Moorish context.

50 Recent promissory note OPCA schemes rely on a passage by Lord Denning in Fielding and Platt Ltd $v$ Najjar, [1969] 2 All ER 150 at 152 (UK CA) which instructs that bills of exchange and promissory notes are "to be treated as cash." See Child Maintenance and Enforcement Commission v Wilson, [2013] CSIH 95; Boisjoli, supra note 31; Servus, supra note 11.

51 RSC 1985, c B-4, ss 188-92. A plausible misinterpretation of these provisions is examined in Crossroads, supra note 11 at paras 61-67. See also Gladue v Asset Recovery Management \& Sales, [1997] AJ No 1251 (QL) (QB); Whitfield v Chrysler Credit Canada Ltd, 2001 ABQB 497, 294 AR 376. A completely absurd scheme based on these same provisions is rejected in Toronto-Dominion Bank $v$ Di Iorio, 2011 ONCA 792, 2011 ONCA 792 (CanLII).

52 Canadian Charter of Rights and Freedoms, Part I of the Constitution Act, 1982, being Schedule B to the Canada Act 1982 (UK), 1982, c 11 [Charter].

53 Mouvement laïque québécois v Saguenay (City), 2015 SCC 16, [2015] 2 SCR 3 at paras 144-49. 
principles means that religious principles or texts have legal and superior authority. ${ }^{54}$ The fact Canadian courts have concluded the "rule of law" preamble language is legally relevant buttresses that argument. ${ }^{55}$ Writers who advance subtle analyses that "supremacy of God" is an oblique reference to natural law $^{56}$ or human dignity ${ }^{57}$ fail to realize that the Charter preamble will be read, interpreted, and applied by ordinary persons, and to them, "supremacy of God" likely means exactly what it says.

These are instances where pseudolaw represents an articulable variation from "real" law. When faced with legal errors of this kind, a court, lawyer, or government actor can make a reasoned response, and more importantly, state what the actual law is, and explain why the pseudolaw is wrong. ${ }^{58}$ However, not all OPCA concepts can be described in any sense as having a logical and rational explanation, when viewed from a "mainstream" legal perspective.

\section{OTHERLAW}

Some pseudolegal concepts and schemes defy rational explanation, and are not tethered in any way to history, logic, legal tradition, methodology, or legal philosophy. This Otherlaw is a unique challenge because it shares no common ground with conventional legal procedures or concepts. Instead, it resembles magic, which anthropologists define as "rituals, by which a person can compel the supernatural to behave in certain ways." 59 Otherlaw is intended to compel courts.

The following three examples illustrate the fundamentally alien context in which Otherlaw OPCA schemes operate.

\section{A. Sympathetic Magic}

Figure 1 reproduces in part an extraordinary document created by Edmund Bruce Hegerat, ${ }^{60}$ which purports to be an "Order" from "The International Criminal Court" in The Hague, Netherlands (the "ICC").

$54 \quad$ See Meads, supra note 8 at paras $280-81$

$55 \quad$ See e.g. Canadian Council of Churches v Canada (Minister of Employment and Immigration), [1992] 1 SCR 236 (Justice Cory cites the preamble to indicate that the rule of law is a "cornerstone of our democratic form of government" at 250); Re Manitoba Language Rights, [1985] 1 SCR 721 (the Supreme Court concludes the "rule of law" "becomes a postulate of our own constitutional order by way of the preamble" at 750).

56 Jonathon W Penney \& Robert J Danay, "The Embarrassing Preamble? Understanding the 'Supremacy of God' and the Charter" (2006) 39:2 UBC L Rev 287.

57 Lorne Sossin, "The 'Supremacy of God,' Human Dignity and the Charter of Rights and Freedoms" (2003) 52 UNBLJ 227.

$58 \quad$ See Netolitzky, "OPCA History," supra note 6 at 637-38.

59 Rebecca L Stein \& Philip L Stein, The Anthropology of Religion, Magic, and Witchcraft (Boston: Pearson, 2005) at 136.

${ }_{60}$ Hegerat was previously associated with the Church of the Ecumenical Redemption International OPCA movement: Netolitzky, “OPCA History,” supra note 6 at 627-28; Meads, supra note 8 at paras 134-39, $183-88$. 


\section{Figure 1: Hegerat INTERNATIONAL Criminal COURT ORDER ${ }^{61}$}

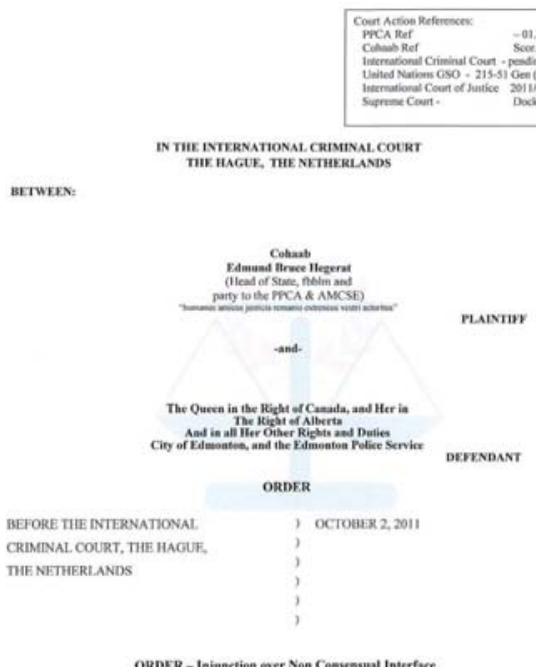

ORDER - Injonstion eoer Non Conumsual Interfoce

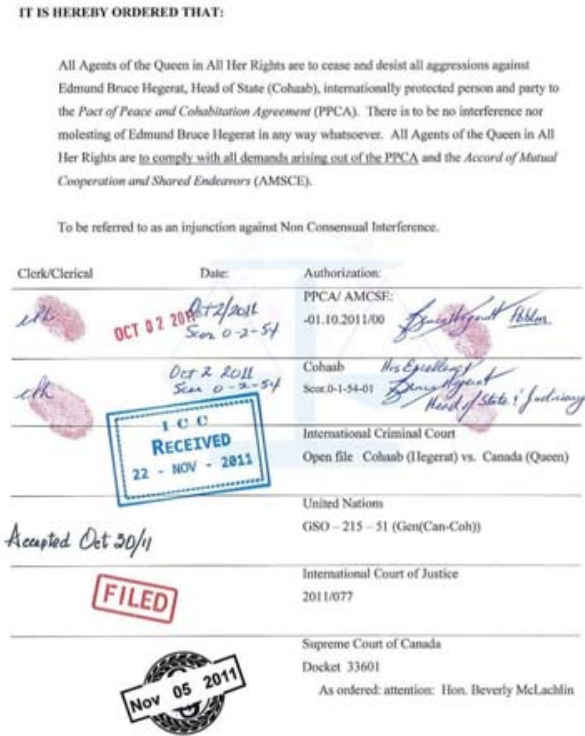

Figure 1: first two of three pages of a purported International Criminal Court in The Hague Order received by the Federal Court on 16 November 2012 in Hegerat v. Canada (Federal Court Docket T-1829-12). 
Examination of the original document very strongly suggests that the markings on page two were not actual stamps or signatures, but instead are computer generated items added via graphics manipulation software.

This particular document was used in court. Hegerat v. Canada includes a 23 November 2012 entry which rejects filing of "two Orders purporting to be from the International Criminal Court received by the Registry on November 16, 2012." ${ }^{\prime 62}$ Both are (purportedly) ICC orders. ${ }^{63}$ One is the document in Figure 1, while the other is a 13 November 2012 "Order" from the ICC that: "All Agents of the Queen in All Her Rights are to cease and desist all delays in the Federal Court of Canada Case T-1829-12. The matter is to set for a sitting in Dignity on or prior to December 13,2012, or as to another date as agreed to by the more vulnerable party, Edmund Bruce Hegerat." 64

It is difficult to ascribe a rational motive to a person who would prepare these documents. Conventionally, these are an obvious, blatant, and ridiculous forgery. The author must have known the ICC order was meaningless. He assembled the various components, adding the various stamps, seals, and signatures. The "Order" is not even vaguely structured in a manner that matches the Court from which it supposedly originates. Instead, the Hegerat document most closely resembles Canadian court documents, and in particular, the format for court orders issued under the pre-2010 Alberta Rules of Court. ${ }^{65}$

Even more confusing is that Hegerat has experience and at least partial success in "conventional" legal proceedings. Between 1997 and 2000, Hegerat appealed an income tax assessment. ${ }^{66}$ The trial decision explains that Hegerat, a chartered accountant, dedicated a substantial amount of his time to inventions and claimed these costs as a tax credit. ${ }^{67}$ An interesting portrait of Hegerat emerges. He is an "eclectic individual" who regards himself as an inventor and entrepreneur, and lived a spartan lifestyle investigating diverse projects including insulating products, board games, variant tarot cards, and a deodorant foot powder. ${ }^{68}$ Hegerat's inventor-based tax credit appeal was unsuccessful, but his GST credit argument was accepted. ${ }^{69}$ The trial proceedings described in the reported decisions and the court docket records appear unremarkable.

Hegerat must have known at some essential level that the ICC documents he created could not be real court orders as he made them himself. Nevertheless, these documents were used as part of an action Hegerat himself initiated.

This paradox illustrates the "ceremonial," "magical," or "symbolic" aspect of certain OPCA materials and litigation. These documents' functionality and effect is entirely outside

(23 November 2012), Vancouver FCTD T-1829-12.

See online: <www.mediafire.com/download/0cdjr4pvaxi4886/Hegerat+-+ICC+orders+\%28FC\%29. pdf $>$.

Ibid.

Alta Reg 390/1968.

Hegerat v Canada, [1999] GSTC 95, rev'd in part [2000] GSTC 48 (CA) [Hegerat].

Ibid.

Ibid at paras 2-4, 14-16. Hegerat's website (online: Edmund Bruce Hegerat $<$ stillhere99.wixsite.com/ edmund-bruce-hegerat>) matches this description, and illustrates some of Hegerat's OPCA beliefs. Hegerat, ibid. 
orthodox legal processes. However, a conventionally useless, false document of this kind possesses "sympathetic magic."70

Sympathetic magic is a magic based on imitation or correspondence. ${ }^{71}$ The classic example of imitative magic is to make a figure, effigy, or fetish of a person or object. Manipulation of this item is then expected to affect its template. Sympathetic magic may also operate by simulation. For example, simulating hunting activities is perceived to cause a subsequent and successful hunt. Manufacturing an image of a prey animal will cause that animal to appear. Representations of a true article hold power.

Sympathetic magic documents are not uncommon in OPCA litigation, particularly in debt elimination schemes. The "private registered set off bonds" in Bossé v. Farm Credit Canada are another example: "It defies logic that one could print out bonds for any sum of money, let alone significant amounts, and simply say to one's creditors 'here, go away, you have been paid.", 72

Sometimes OPCA sources are quite up front about the "magical" aspect of documents. For example, the UK OPCA debt elimination website Get Out Of Debt Free (GOODF) offers a template promissory note that has "incorporated powerful sacred geometry." 73

More recently, the Alberta Court of Queen's Bench concluded that cheques sold by a fictional and fraudulent UK bank, the "WeRe Bank," had no associated value. ${ }^{74}$ Customers of the WeRe Bank paid its operator, "Peter of England," $£ 35$ in exchange for a book of "WeRe Cheques" that supposedly could pay off large debts. Superficially, a WeRe Cheque does resemble a bank cheque, ${ }^{75}$ however, Peter of England never promises to pay cash on behalf of his customers; instead he sends "Re Energy Units," which are "units of time and space."76

Sympathetic magic extends to in-court behaviour. One Alberta OPCA litigant appeared in court wearing lawyer's robes, saying that allowed him to represent others. ${ }^{77}$ Others point to a "Power of Attorney."

The only explanation for sympathetic magic is that some OPCA litigants simply do not understand or accept that legal and court processes apply an underlying schema or logic. Symbolic power is real power. If one wears the correct mask, you are the player.

James George Frazer, The Golden Bough: A Study in Magic and Religion (New York: MacMillan Company, 1925) at 11-48. See also Marcel Mauss, A General Theory of Magic, translated by Robert Brain (London: Routledge Classics, 2001).

71 The concept of sympathetic magic and its characteristics were developed in the late 19th century by early anthropologists. See ibid.

Bossé, supra note 11 at para 42.

Canadian Imperial Bank of Commerce v McDougald, 2017 ABQB 124, 98 CPC (7th) 181 at paras 30, $56[$ McDougald $]$.

Servus, supra note 11 at paras 54-74; see also Scotia Mortgage Company v Morrison, 2016 BCSC 1567, 270 ACWS (3d) 865; McLeod v Prestige, [2016] CSOH 69.

Servus, ibid attaches a sample WeRe Cheque as Appendix D.

Ibid at paras 59, 61 .

Meads, supra note 8 at para 312.

See e.g. Fiander, supra note 11 at para 8; Perreal, supra note 32 at 37-39. 


\section{B. Cargo Cult Law}

OPCA materials are often formatted and marked in complex ways, for example structuring a name in an unusual manner, ${ }^{79}$ the use of specific titles,${ }^{80}$ display of coat of arms or flags, ${ }^{81}$ and signing documents with specific ink colours or blood. ${ }^{82}$ The resulting documents are sometimes unusual and dramatic, as is illustrated by the Moorish Law document in Figure 2. Associate Chief Justice Rooke in Meads suggests these motifs are intended to impress gurus' customers via their theatrical effect. ${ }^{83}$

\section{FIGURE 2: YANKSON MOORISH LAW “AFFIDAVIT"}

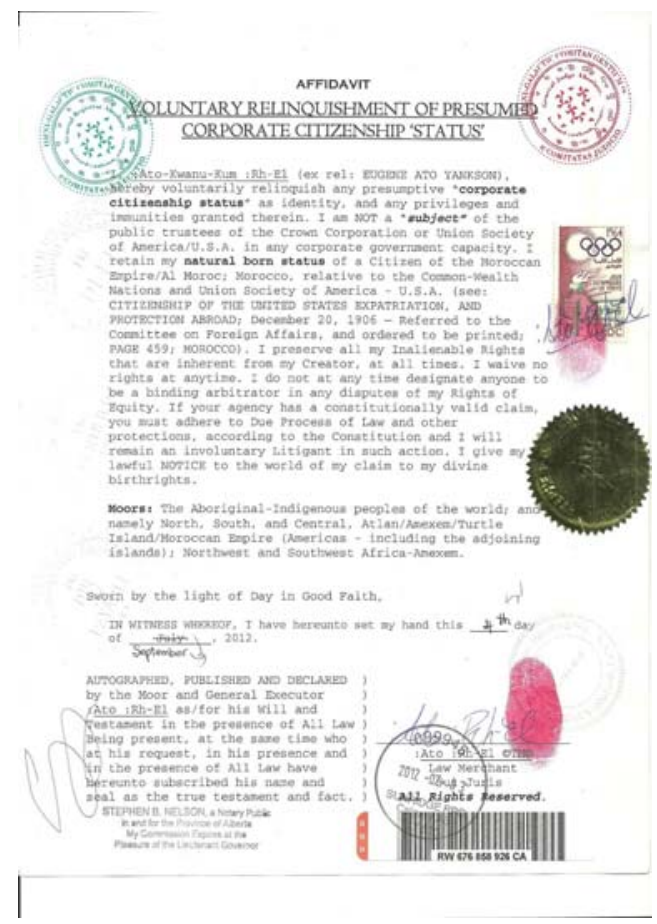

Figure 2: "Affidavit" by Eugene Ato Yankson (also known as Ato-Kwanu-Kum :Rh-El) claiming Moorish Aboriginal status and immunity to state authority filed in Yankson $v$ City of Calgary, Calgary 1201-07644 (Alta QB). Yankson unsuccessful sued Calgary for $\$ 10,311,340.00$, alleging Calgary Police Service officers had no authority to arrest Yankson for drug-related misconduct. Note the Moroccan stamp, signature, and ink fingerprint.

Meads, supra note 8 at paras 206-13.

Ibid at paras 221, 319 .

Flags are a key component of documents prepared according to techniques taught by US OPCA guru David Wynn Miller (see Part III.B.1.b, below) and also featured prominently in JM Sovereign:Godsent, Title 4 Flag Says You're Schwag!: The Sovereign Citizen's Handbook (Sovereignty Press: 2009) [Title 4 Flag 2009].

82 Meads, supra note 8 at para 215.

$83 \quad$ Ibid at para 77 
A common but strange feature of many OPCA documents is one or more postage stamps attached at various locations. One common variation is a postage stamp attached to the upper right corner of the first page of an OPCA document. Another has the postage stamp located at the document signature line. Sometimes stamps are located on the back and otherwise empty pages of a document. In almost every case these postage stamps are then "cancelled" with a signature, initials, or other markings printed across the stamp.

The cryptic postage stamp ornament illustrates a second kind of magical Otherlaw: cargo cult pseudolaw. While sympathetic magic pseudolaw creates obviously false and symbolic copies of a genuine article, cargo cult pseudolaw attempts to imitate things the users do not understand, but whose power and authority are, presumably, seen as desirable.

The cargo cult name derives from an unusual social and religious movement which emerged in Melanesia. The best known example was islanders who had seen US and Japanese military activities and encountered a wealth of sophisticated goods. After World War II, they attempted to obtain "cargo" by mimicking the structures and behaviours that they had observed, for example, building imitation aircraft and flight facilities, airstrips, control towers, and imitating what they had seen, performing simulated parade ground and patrol drills. These activities were intended to attract more aircraft and airdrops of new "cargo." 84

What makes the cargo cult pseudolaw character of the postage stamp motif obvious is that OPCA litigants and gurus have no single explanation for the function postage stamps perform. Instead, the postage stamp motif is explained by many different alternative and incompatible theories, and for conflicting purposes.

\section{The Universal Postal Union}

The most sophisticated explanation of the postage stamp motif is that postage transforms a document into correspondence, which is governed by the Universal Postal Union (UPU) and the international treaties that manage international mail. Purportedly, the postage stamp transforms an OPCA affiliate into a full-fledged nation-state with equal rights and peer status to countries such as Canada and the United States. Stamps makes the OPCA affiliate a "Postmaster."

The UPU is an international body that coordinates the interactions of national post offices. Initially formed in 1874 as the General Postal Union, it is the second oldest international organization, and in 1948 became a specialized agency of the United Nations. ${ }^{85}$ There are 192 countries that are members. ${ }^{86}$ The UPU manages the transfer of mail between different countries and replaced earlier bilateral postal treaties. The UPU scheme has three key components: popular cargo cult narratives focus on the post-World War II period, this phenomenon has a much longer history, with earlier efforts intended to summon steamships carrying cargo.

86 See online: Universal Postal Union $<$ www.upu.int/en/the-upu/member-countries.html $>$. 
1. Mail sent from one country to any other country should have a uniform flat rate,

2. a national postal service should treat foreign and domestic mail the same, and

3. each country retains money collected for mail exiting that country into other jurisdictions. ${ }^{87}$

This approach to international mail has proven an economic and logistical success because the cost of correspondence between any two countries is generally equal in each direction, therefore, neither post office incurs disproportionate costs when handling mail from the other nation. ${ }^{88}$

This arrangement has interesting consequences when viewed through the lens of contract law. A contract exists between a local postal service and a person who pays that postal service to deliver mail. However, if mail is delivered to a different country then any relationship to the foreign postal service is non-contractual. There is no consideration transferred from the sender to the foreign post office. Rather, the obligation on the foreign post office flows from the Treaty of Bern ${ }^{89}$ and the UPU.

A common OPCA concept is that government authority derives solely from contract. ${ }^{90}$ OPCA affiliates attempt to avoid "joinder": entering into contracts that will (allegedly) create government and court authority. These contracts can (allegedly) result from practically any voluntary interaction with government or use of its programs. ${ }^{91}$ Funneling activities through the UPU and its unusual arrangement therefore provides a mechanism to avoid contractual relationships with state actors.

Many OPCA schemes invoke the UPU and postage stamps. What follows are a few examples.

\section{a. WebMavin}

The "WebMavin" website ${ }^{92}$ provides an explanation of the UPU and postage stamp motif. It claims the postmaster general is superior to all other government authorities because that office preceded the US, and due to a passage in an 1825 Act to regulate the post office: "That there be established, at the seat of the government of the United States, a general post office, under the direction of a postmaster general., 93

Francis Lyall, International Telecommunications: The International Telecommunications Union and the Universal Postal Union (New York: Routledge, 2016); FH Williamson, "The International Postal Service and the Universal Postal Union” (1930) 9:1 J Royal Institute Intl Affairs 68.

88 Ibid.

89 Treaty of Bern, 9 October 1874, 19 US Stat 577. This treaty was later incorporated into the Constitution of the Universal Postal Union in 1964. Meads, supra note 8 at paras 388-416.

This concept appears in a highly-developed form in George Mercier, Invisible Contracts (self-published, 1986) that circulated on US Tax Protestor and Militia bulletin board systems. Invisible Contracts was subsequently published by the Law Research Group as a book in 2004.

92 See online: <www.webmavin.com>. WebMavin offers OPCA debt elimination services via "private administrative processes," which is another name for the Three/Five Letters foisted unilateral contract scheme. See supra note 33.

3 Story, US 1825, s 1 [1825 Act]. 
WebMavin claims "the seat of the government of the United States under the direction of a postmaster general," 94 and concludes that the US Postal Service may even function as a backup or replacement government, but the actual legislation reads: "[ $\mathrm{t}] \mathrm{h}$ at there be established, at the seat of the government of the United States." 95 This is an example of how subtle misquoting of genuine legislation leads to a spurious conclusion.

Placing a postage stamp on a document makes a document "official," and "invokes postal statutes" and UPU jurisdiction. A \$1 "Red Fox" stamp is preferred. The litigant signs across the stamp, and dates it: "to comply with postal regulations concerning private mail carriers, and to make a continuance of evidence that the process (paper work) is mail." ${ }^{\prime 96}$ The result not only establishes the litigant as an independent nation, but also removes conventional government authority by "taking the Post-Office and the judicial system back some two hundred years." 97 Interactions with the court are now mediated by "postal statutes" and uncooperative court actors can be sued "offshore for adjudication in any court in the world." 98

WebMavin further alleges the UPU is the ultimate military and commercial authority due to its association with the International Monetary Fund; all countries are bankrupt and foreclosed; using a postage stamp and autograph "makes you the postmaster"; a postmaster's jurisdiction is superior to all other authorities; and recipients of these documents "back off." 99

A postage stamp invokes the authority of the UPU, and permits use of UPU remedies "under international law and treaty," which is superior and beyond a court's jurisdiction: "[e]verything is commerce, and all commerce is contract. The master of the contract is the post office, and the UPU is the supreme overlord of the commerce, banking, and postal systems of the world. Use of these stamps in this manner gets the attention of those in the system to whom you provide your paperwork. It makes you the master of that post office."100

Certain stamps and formalities have different effects. Signing the stamp is critical: "[w] henever you put a stamp on a document, inscribe your full name over the stamp at an angle. The colour ink you use for this is a function of what colour will show up best against the colours in the stamp. Ideal colours for doing this are purple (royalty), blue (origin of the bond), and gold (king's edict). Avoid red at all cost." 101

Location is also significant:

On foundational documents and checks, for instance, put a stamp on the right hand corner of the instrument, both on the front and on the back. The bottom right hand corner of the face of a check, note, or bill of exchange signifies the liability. Furthermore, the bottom right hand corner of the reverse of the document is

"Why We Are in the Admirality Jurisdiction" (11 October 2015), online: <www.webmavin.com/2015/ 10/11/why-we-are-in-the-admirality-jurisdiction/>. 1825 Act, supra note 93 [emphasis added]. Supra note 94.

Ibid.

Ibid.

"Postal Power" (11 October 2015), online: WebMavin <www.webmavin.com/2015/10/11/postalpower/>.

Ibid.

Ibid. 
the final position on the page, so no one can endorse anything (using a restricted endorsement or otherwise) after that. You want to have the last word. If you have only one stamp, put it where you are expected to sign and autograph over it cross-wise. ${ }^{102}$

The sides of court document pages indicate different jurisdictions: "one side is criminal and the other is civil." 103 Putting a stamp on the back of a page means the litigant is immune to criminal consequences as "there can be no assessment for criminal charges, and you show that you are the holder of the civil assessment, there is no way out for the court."104 WebMavin suggests hiding stamps on the back of pages to avoid alarming court clerks. ${ }^{105}$ This prevents the stamp from being mutilated, "one of the tricks of judges these days."106

The WebMavin postage stamps explanation appears to date back to around 2004, but was possibly copied from an earlier unidentified source. It is reproduced widely in OPCA circles, though often without reference to WebMavin. As is often the case, the scheme and its components have become increasingly elaborate as each guru adds his or her own elements. The Freedom School variation marks stamps with dates, a social security number, a red ink thumbprint, and two names: one in the "dash colon" format, the other a combination "dash colon" and "of the family" variation. ${ }^{107}$

US guru Jaemes (James) McBride reproduced the WebMavin instructions in his book The Divine Province, ${ }^{108}$ but frames his role and the UPU in a different context. McBride explains that the Vatican has legal title to the world, and operates the UPU as a continuation of Biblical/Roman postal services. ${ }^{109}$ McBride claimed he seized the abandoned office of Postmaster General for North America, and as a consequence created a new jurisdiction, the Divine Province. ${ }^{110}$ This authority was conveyed by a Vatican seal, which McBride displayed along with other Divine Province paraphernalia in a television interview. ${ }^{111}$ This scheme was popular. McBride reportedly received over $\$ 500,000.00$ from the sale of Divine Province materials. ${ }^{12}$

\section{b. Federal Postal Court — David Wynn Millar}

US OPCA guru David Wynn Miller ${ }^{113}$ emphasizes the UPU scheme, and may be its inventor. Miller's basic theory is that documentation can only have legal effect if it conforms to an unorthodox grammar taught by Miller. Documents written in "Millerese" are a

\footnotetext{
102 Ibid.

103 Ibid.

104 Ibid.

105 Ibid.

106 Ibid.

107 "Universal Postal Union," online: <www.freedom-school.com/evidence/universal-postal-union.pdf $>$.

108 Jaemes McBride \& Ed Rychkun, The Divine Province: Birthing New Earth (self-published, 2013) at $580-83$.

$109 \quad$ Ibid at 571-79.

110 Archived partial website, online: $<$ https://web.archive.org/web/20121204162444/http://divineprovince. org/>.

111 ABC News, “'Divine Province’ Leader Says He Hasn’t Paid Income Tax in 26 Years” (12 April 2013), online: <abcnews.go.com/2020/video/divine-province-leader-paid-taxes-26-years-18942052>.

112 Matthew Barakat, "Divine Province' Hoaxer from Central Ohio Sentenced to Prison," The Columbus Dispatch (28 November 2014); Jim Woods, “'Sovereign Citizens' Can Be Risk for Police," The Columbus Dispatch (22 February 2014). 
challenge to interpret, but typically include postage stamps in their upper right corner that are signed through with additional text. ${ }^{114}$

Miller has been directly and indirectly involved in many OPCA cases worldwide, including Canada, ${ }^{115}$ Australia, ${ }^{116}$ New Zealand,,${ }^{117}$ and at least 110 post-2004 US lawsuits. ${ }^{118}$ In Wollongong City Council v. Falamaki he explained the role of stamps on court documents:

That's a maritime vessel. It's got a stamp on it. It's a vessel. All paper is a vessel in a sea of space and therefore it has to fly a vessel. It has to pay its postage to go between point A and point B. The bailiff over here is actually the letter carrier to transport the letter from myself to you. The postage has been paid on my letter, to go to you so that you could mark it as evidence. ${ }^{119}$

Miller also shared a grammar secret: "[e]very word that starts in the English language with a vowel, a, e, i, o and $u$ and followed by two consonants is a word that means no contract."120 Unsurprisingly, Craig J. did not find these submissions helpful.

More recently, Miller claims to have "re-established" the US :FEDERAL-POSTALCOURT, ${ }^{121}$ and has issued default judgments on that basis. Gilly v. Ocwen reports a "show cause" hearing where Miller, as judge of the "Federal Postal Court," explained the "court's" operation, and how he reopened that court on 21 December 2012 (the so-called Mayan Doomsday). ${ }^{122}$ US District Judge Meyer refused to file the Federal Postal Court default judgment and concluded "the 'Federal Postal Court' is a sham and no more than a product of fertile imagination.". 123

The current status of Miller and the Federal Postal Court is unclear. Its websites are offline. ${ }^{124}$ Miller's long-time collaborator, Russell Jay Gould, has recently published a Youtube “:Field-Court-Martial-Hearing” video which purportedly removed Miller's authorities, following a heart attack. ${ }^{125}$

See e.g. an identification document for Canadian OPCA litigant David August Lange, online: <www. mediafire.com/file/943s0v9f72p9b0p/Lange - Millerite ID document.jpg $>$.

National Leasing v Top West Venture, 2001 BCSC 111, 2001 BCSC 111 (CanLII); CIBC v Chesney, 2001 BCSC 625, 2001 BCSC 625 (CanLII); Borkovic v Laurentian Bank of Canada, 2001 BCSC 337, 2001 BCSC 337 (CanLII); $R v$ McMordie, 2001 BCCA 412, 155 BCAC 21. Wollongong City Council v Falamaki, [2010] NSWLEC 66 [Wollongong \#2]; Wollongong City Council $v$ Falamaki, [2009] FMCA 1204.

Online: Justia $<$ https://dockets.justia.com/search?parties=\%22David+Wynn+Miller\%22>.

Wollongong \#2, supra note 116 at para 36.

Ibid at para 35.

Archived websites, online: Internet Archive <https://web.archive.org/web/20160310022317/http:// thefederalpostalcourt.weebly.com $>$; online: Internet Archive $<$ https://web.archive.org/web/2017061513 5008/http://federalpostalcourt.org/>.

Ibid at 4.

Ibid.

Pamela Horton, “:STAND-DOWN OF THE :David-Wynn: Miller.” (23 August 2017), online: <https:// www.youtube.com/watch?v=WXc0shnGGmE $>$. 


\title{
c. Title 4 Flag Says You're Schwag
}

Another variation on the UPU postage stamp scheme appears in a curiously titled book, Title 4 Flag Says You're Schwag: The Sovereign Citizen's Handbook, by J.M. Sovereign: Godsent. ${ }^{126}$ For lack of a better description, this scheme transforms a person into a piece of international mail via a "Claim For Your Life" document. It requires a properly formatted name, a photo, a "Title 4 flag" graphic in the upper left corner, a \$1.00 US postage stamp on the upper right corner, an ink right thumb print, and a sample of DNA in the form of blood. The document is then sent by registered mail to its author. The alleged result of this ceremony is:

\begin{abstract}
When this is done you will be relieved because your Sovereignty will then be internationally documented in the UNIVERSAL POSTAL UNION database. This government issued ID proves beyond a reasonable doubt that you are a SOVEREIGN LIFEBIRTH-PARTY WITH THE TITLE 4 FLAG and is more powerful than a passport. ${ }^{127}$
\end{abstract}

Government actors who interfere with the sovereign individual are liable to a $\$ 1,000,000.00$ fine for mail fraud. This document also allegedly permits the author to "Mail Yourself Across the Border" because the "Universal Postal Union Worker's Treaty" 128 makes police, customs, and court staff postal clerks: "[s]o, you can put a stamp for the country you wish to travel in on your CLAIM FOR THE LIFE and have the customs agent cancel the stamp at the border, thereby mailing your package(self) into the country."129

This peculiar scheme shows an obvious David Wynn Miller influence, and, unsurprisingly, Title 4 Flag openly acknowledges Miller. ${ }^{130}$

\section{d. UPU Schemes}

The UPU scheme is obviously false. The UPU is not the supreme world authority, but instead operates an international treaty between nations. Putting stamps on a document does not make one a nation state or a piece of postage. Nevertheless, the UPU postage stamp explanations are clever in how they adapt the UPU and its operation to reframe the usual laws that govern service-related interrelationships. Another obvious point is UPU OPCA procedures are very ceremonial. Much is not explained, but is simply identified as important.

\section{Postage Stamps Are Consideration}

Another explanation is that postage stamps on a legal document are consideration for an enforceable contract. There is a logic to this scheme, since postage stamps serve that function when mailing correspondence.

Title 4 Flag 2009, supra note 81. The most recent edition is H.I.R.M. J M Sovereign: GodsentTM, Title 4 Flag Says You're Schwag!: The Sovereign Citizen's Handbook, version 3.2 (Sovereignty Press: 2013) [Title 4 Flag 2013].

Title 4 Flag 2009, supra note 81 at 53.

Perhaps unsurprisingly, there is no such treaty.

Title 4 Flag 2009, supra note 81 at 53-54; Title 4 Flag 2013, supra note 126 at 126-32.

Title 4 Flag 2009, ibid at 5 . The 2013 edition does not include a corresponding passage. 
However, Australian OPCA litigant Darryn (Darren) Stuart Sproule, unsuccessfully argued he had paid an outstanding $\$ 436,472.14$ tax debt by sending the Australian Taxation Office two bills of exchange, including one with an AUD\$1.00 postage stamp attached. ${ }^{131}$

Sproule's written argument stated that "[a] postage stamp attained from Australia Post Office was affixed to a Bill of Exchange as sufficient alternative consideration to constitute a simple contract." 132 The same or a very similar argument was used in an Australian foreclosure action where a Shona Dimetry McLean argued she had paid her \$2.4 million mortgage debt with a purported bill of exchange and other documents "including the postage stamp alleged to constitute the payment in satisfaction of the debt."133

\section{Postage Stamps Are Lawful Money}

A third postage stamp motif involves a Sovereign Citizen concept that most conventional currency is not "lawful tender," but gold and silver coins are the exception. ${ }^{134}$ This is a US OPCA concept where persons reject paying income tax on "Federal Reserve Notes" (that is, paper money), which are not "lawful tender." 135 An Australian version of this concept has also been reported. ${ }^{136}$

US OPCA guru David Merrill ${ }^{137}$ classifies postage stamps as lawful money. He argues that to obtain lawful money one must expend lawful money: "You establish your right to lawful money by cancelling its value." 138 Signing across a postage stamp therefore changes the legal rights associated with a claim document. ${ }^{139}$ Merrill, however, cautions that doing so is "defacing currency of the US," and a crime, "[u]nless you are in the sovereign position to cancel value." 140 Arguably, this is a variation on the "postage stamps are consideration" explanation.

Deputy Commissioner of Taxation v Sproule, [2012] FMCA 1188.

Ibid at para 11. Sproule coupled his bills of exchange argument with what appears to have been a Three/Five Letters process (see supra note 32) that allegedly forced the Australian Taxation Office to accept the bills of exchange and postage stamp as payment, and established the alleged tax debt was not proven.

McLean $v$ Westpac Banking Corporation, [2013] FCA 126 at para 44.

See Harris, supra note 7 at 279. Toronto-Dominion Bank v Devries, 2013 CanLII 41978 (Ont Sup Ct (Sm Cl Div)) involves an analogous argument concerning "fiat currency."

Unsurprisingly, US courts have rejected this concept (United States v Daly, 481 F (2d) 28 (8th Cir 1973); United States v Condo, 741 F 2d 238 (9th Cir 1984); United States v Rickman, 638 F 2d 182 (10th Cir 1980)), which the US Internal Revenue Service classifies as a frivolous tax argument: "The Truth About Frivolous Tax Arguments" (March 2014), online: <https://www.irs.gov/pub/irs-utl/ friv tax.pdf $>$.

Krysiak v Carruthers, [2012] WASC 472, aff'd [2013] WASCA 210; Krysiak v McDonagh, [2012] WASC 270, aff'd [2013] WASCA 100.

Merrill, whose full name is David Merrill Van Pelt, operates a for-pay instructional website. See online: Lawful Money Trust $<$ www.lawfulmoneytrust.com $>$ and the Saving to Suitors' Club web forum, online: Saving to Suitors' Club $<$ savingtosuitorsclub.net $>$.

See online: David Icke Forum $<$ forum.davidicke.com/showthread.php?t=95510>.

Ibid. See also online: Saving to Suitors' Club < savingtosuitorsclub.net/archive/index.php/t-550.html>. Icke, ibid. 


\section{Postage Stamps Create Common Law Copyright}

UK OPCA gurus Jon Witterick and Colin "Ceylon" Haining operate the GOODF OPCA website. ${ }^{141}$ They offer members a Definitive User Guide, which explains that a postage stamp creates common law copyright in a personal name. ${ }^{142}$ A specific Copyright Notice form is required, and a national postage stamp is then placed in the lower right corner of the form.

The user then runs the document through a printer so that a round stamp-like mark which includes a name, date, and "Copyright" is superimposed on the top left of the postage stamp, while a second line of text reading "[FIRSTNAME] [LASTNAME] TM," inclined running up and to the right, is placed over the lower right part of the postage stamp. ${ }^{143}$ The Definitive User Guide stresses these markings must overprint the postage stamp.

GOODF explains copyright in one's own name is a basis to fine persons who use that name without permission, such as banks, courts, and so on. This is a surprisingly common OPCA motif, which Associate Chief Justice Rooke in Meads characterized as having "an

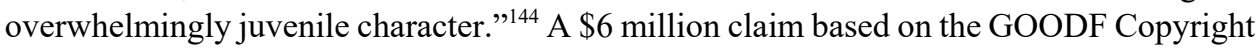
Notice was reviewed and rejected in Bank of Montreal v. Rogozinsky. ${ }^{145}$ This decision reproduces the GOODF Copyright Notice as an appendix, which discloses the claimed intellectual property also extends to biological features, biometric data, DNA, urine, and feces.

\section{Postage Stamps as an Anti-Counterfeiting Measure}

UK Freeman-on-the-Land guru Veronica: of the Chapman family describes another postage stamp motif in her book Freedom Is More Than Just A Seven-Letter Word. ${ }^{146}$ Chapman warns that one should never sign documents other than contracts. Authorities forge signatures to meet their objectives. She therefore suggests signing documents over a postage stamp. That "makes it very hard to extract that segment of your signature."147 Chapman offers no explanation of why a stamp should be used, instead of some other "foreign" substrate for the signature.

\section{ExOTIC ApPlicAtions of Postage Stamps}

Postage stamps on court documents is one thing, but there are reported incidents of even more unusual pseudolegal applications of postage stamps. Christopher Henry Gerlitz, an OPCA tax evader, attached postage stamps to his arm, and "refused to remove them on the

GOODF focuses on debt elimination techniques. See online: $<$ www.getoutofdebtfree.org $>$. See also Netolitzky, "OPCA History," supra note 6 at 631.

Jon Witterick \& Ceylon, getoutofdebtfree.org: The Definitive User Guide, 2nd Canadian ed (getoutofdebtfree.org, 2012) at 17-18, 24-25. GOODF publishes a variety of "localized" versions of this text.

Ibid at 17, 24 illustrates the intended result.

Meads, supra note 8 at para 504. See also ibid at paras 494-503.

Supra note 11 at paras 80-87. See also McDougald, supra note 73 at para 27.

Veronica: of the Chapman family, Freedom ... Is More Than Just a Seven-Letter Word, 2nd ed (London: TamaRe House, 2010). Chapman operates the "FMOTL.com" website (online: <www.fmotl.com $>$ ) and acknowledges she advances Freeman-on-the-Land concepts from several Canadian gurus. Ibid at 70 . 
basis the stamps belonged to the universal postal service." 148 The source or sources for Gerlitz's OPCA beliefs are unknown. Perhaps the postage stamps made Gerlitz a piece of mail, and subject only to the UPU.

Two Calgary residents, Paul and Myrna Schuck, reportedly at trial for failure to produce income tax records, wrote their names on postage stamps, and then attached those to laminated identification badges. This process allegedly made them the equivalent in authority to the Queen of England. ${ }^{149}$

Supporters of the Schucks did the same and one, ":Richard-Gerald:Mongeon," stated "[b]y autographing a postage stamp you become a postmaster and become equal with the Queen of England." ${ }^{150}$ Unsurprisingly, this technique was ineffective. The Schucks were convicted and received 30-day prison sentences. Contemporaneous communication in a Detaxer online forum indicates the Schucks attempted to implement David Wynn Miller's teachings. ${ }^{151}$

British Columbia litigant Erwin Badertscher operates a website with yet another variation on Miller's postage stamp concept: custom-made "Millerese" licence plates with postage stamps that Badertscher offers for CDN\$45.00. ${ }^{152}$

\section{The Postage Stamp Motif has No Consistent Explanation}

Comparing these various schemes leads to a peculiar conclusion. OPCA litigants believe placing postage stamps on their documents is important, but they have no consistent explanation for why this step has special or legal significance.

Nor is there an obvious way to organize these various schemes, so one concept is derived from another, though some explanations are obviously related. Sometimes postage stamps serve as a form of currency. Other times they create unique jurisdictional status. Sometimes the UPU is important. Other times it is irrelevant; the stamp creates copyright or is a security feature. The exact postage stamp formalities vary, but several elements often reappear, such as the location of the stamp should be in the upper right corner of a document. The one common step is that signing across or otherwise marking the postage stamp is necessary.

The lack of a clear explanation for the postage stamp motif and the importance of the signature suggests that any explanation for the postage stamp motif is not based on a scheme or logic. Rather, the originator(s) of the postage stamp motif were trying to imitate something they had seen and concluded was important, but which they did not understand. But what could motivate someone to place a postage stamp on a court document, then sign across it?

$R v$ Gerlitz, 2014 ABQB 252, [2015] 2 CTC 105 at paras 8, 19.

Shelley Knapp, “Consumers Warned to File Out of Anti-Tax Forum: Group's Literature Claims Paying is Voluntary," Calgary Herald (22 September 2001) B10.

Grady Semmens, “Airdrie Couple Gets 30 Days After Chaos in Court: 'Foolishness' Frustrates Judge in Tax Case," Calgary Herald (1 August 2001) B8.

See online: $<$ lists.topica.com/lists/Important/read/message.html? $\mathrm{mid}=803742060>$.

See online: $<$ https://web.archive.org/web/20170729152354/http://www.fight-4-truth.com/Facts.html>. 


\section{LAW AND REVENUE STAMPS}

Figure 3 illustrates a plausible answer to the aforementioned question.

Figure 3: SUPREME COURT OF CANADA

BiLl OF ResPondent's Costs, 1926, ATtAChing LaW STAMPS
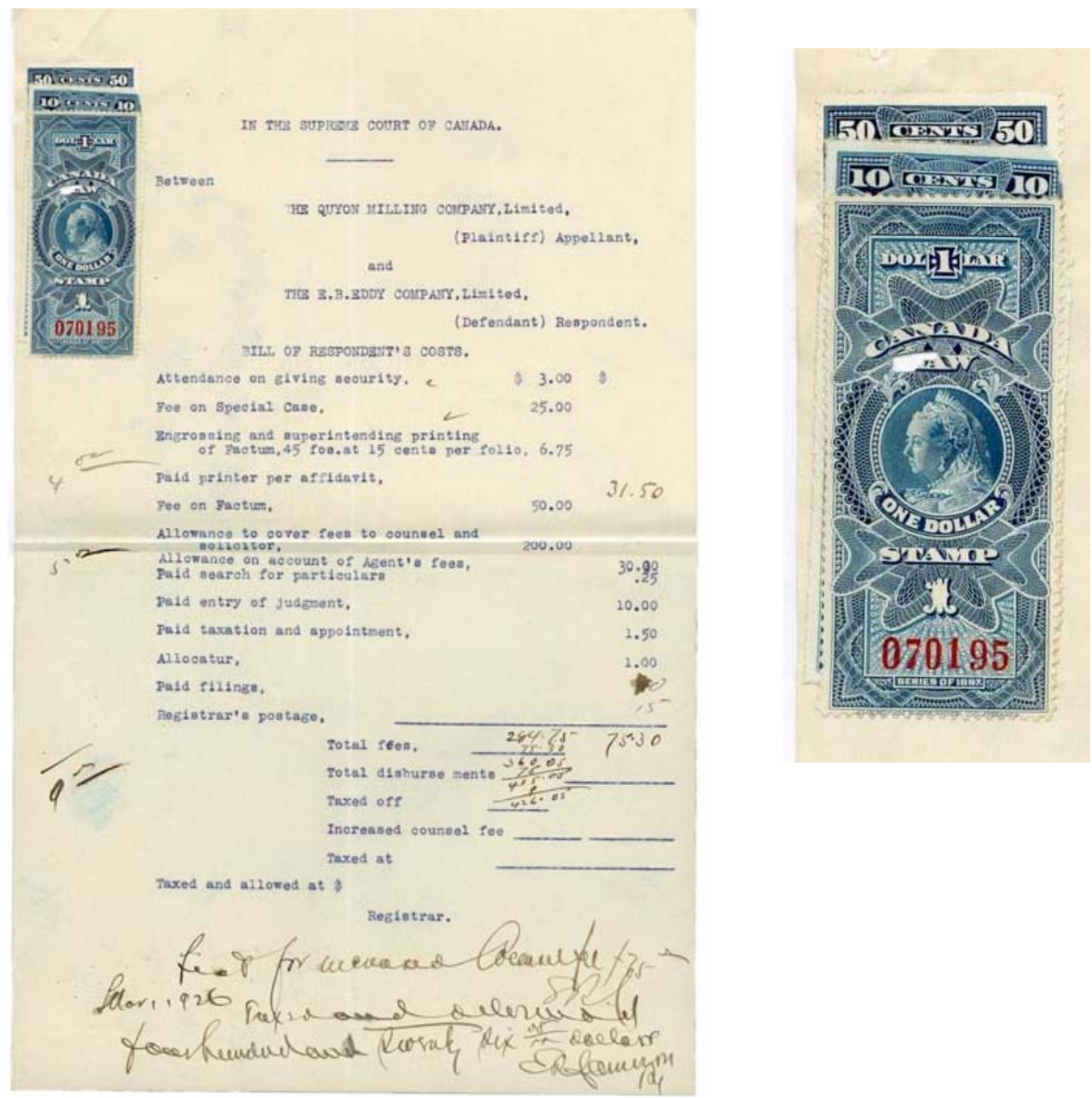

Figure 3: Respondent's Bill of Costs from Quyon Milling Co. Ltd. v. E. B. Eddy Co. Ltd., [1926] SCR 194, dated 1 November 1926. Left panel illustrates the document as a whole, while the right panel shows a magnified view of three overlapping Supreme Court of Canada law stamps attached to the Bill of Costs to pay the $\$ 1.60$ document filing fee. The three stamps have been cancelled by a punch to mark the stamps as used.

During the 1800s and onward into the twentieth century, many Canadian courts only accepted payment of court filing fees by law stamps. Law stamps were purchased from the court clerk. A lawyer who sought to file a document placed the law stamp or stamps on the front of the document, usually in a corner. The clerk then cancelled the law stamp, often with 
a signature, but sometimes with an inked stamp, or a hole punch. ${ }^{153}$ The law stamp system is therefore homologous to how postage stamps pay for postal fees.

Law stamps are a subclass of revenue stamps, a larger category of paper stamps attached to items for a variety of reasons, such as to indicate duty or a tax had been paid on a product, that an item had been inspected or passed through customs, or to track restricted quota activities. In each case the scheme is basically the same: a party purchases the stamps to pay for a fee, then physically attaches a stamp to conform to a state requirement. Revenue stamps predate postage stamps by several centuries, and are still occasionally encountered, for example, sealing packages of tobacco products imported from other jurisdictions. ${ }^{154}$

In Canada law stamps were gradually discontinued, with the Federal Courts and Supreme Court of Canada abandoning the practice in 1967. ${ }^{155}$ Alberta used law stamps from 19061930, British Columbia from 1879-1981, Manitoba from 1877-1901, New Brunswick from 1884-1977, Ontario from 1864-1940, Quebec from 1864-1923, and Saskatchewan from 1907-1968. ${ }^{156}$ The Halifax Law Library and Halifax Barristers Society also issued stamps, apparently for legal documents. ${ }^{157}$

Louisiana was the only US jurisdiction to use dedicated law stamps, however, standard government issued revenue stamps were used on legal documents from 1862-1873, then again between 1898-1901, and for land deeds only between 1914-1967. ${ }^{158}$ US postage stamps have never been used with court documents (at least legitimately).

The timing of court document law and revenue stamps in the US and Canada is interesting. They pre-date the broad appearance of OPCA litigation by decades, so OPCA litigants would never have been required to use law stamps, but it is conceivable they would periodically encounter these stamps on older legal documents.

My hypothesis is that at some point one or more OPCA litigants encountered law or revenue stamps attached to court documents, discovered those stamps were no longer available, concluded that stamps were, nevertheless, an important formality, and then set out to imitate that by attaching postage stamps to their court documents. They likely would have been unable to learn much about the stamps given the time that had elapsed. Since law stamps were no longer available, they used the nearest equivalent with which they were familiar. The timing of legitimate stamps on court documents also supports this cargo cult explanation. Sovereign Citizen theory holds that US law and court processes were corrupted at some point, most often the 1930s. By imitating a pre-1930 motif, the first "postage stamp

See e.g. Christopher D Ryan, "Notes on the Law Stamps of Ontario and the Province of Canada, Part 2" (2000) 2:32 Canadian Revenue Newsletter 3 (for Ontario).

154 Christopher D Ryan, "An Introduction to Canadian Revenue Stamps" (2015) at 8, online: British North America Philatelic Society <www.bnaps.org/ore/Ryan-RevenueIntro/Ryan-Revenue-Intro-Rev2-2015. pdf $>$; Christopher D Ryan, “Canada's New Tobacco Excise Duty Stamps Finally in Use!”2:72 Canadian Revenue Newsletter 1 . ESJ van Dam, The Canadian Revenue Stamp Catalogue (Toronto: Unitrade Press, 2009) at 16-18. Ibid at 36-37, 39-42, 49-54, 59-61, 72-74, 78-80, 85-86.

Ibid at 67-69.

Personal communication, Richard Friedberg (15 November 2015). The author thanks Mr. Friedberg, an expert in revenue stamps and dealer in revenue stamps as collectables, for generously sharing his expertise in US revenue stamps and the potential legitimate historical uses of postage stamps with legal documents. 
guru" may have believed he was placing his court documents into an older "uncorrupted" regime.

For whatever reason, the practice stuck, and then OPCA gurus reverse-engineered explanations for the purpose of the postage stamps and signature. Some are actually close to the mark, and indicate this is a kind of payment. However, the manner in which the stamps are "cancelled" - by the document creator — strongly implies the OPCA gurus did not really know the true purpose of the revenue stamps they were mimicking, otherwise OPCA postage stamp schemes would have the court clerks sign the stamps. Notably, this alternative does not occur in the explanations identified.

The weakness of this narrative for the pseudolegal use of postage stamps on court documents is that even though an explanation for a historical event may make sense, that does not actually prove what happened. A logical hypothesis for a historic phenomenon is a "just so story," unless supported by additional evidence. That said, the author is confident that modern OPCA applications of postage stamps ultimately flow from a cargo cult attempt to imitate law and revenue stamps on court documents. What else could have seeded the idea to place postage stamps on court documents?

\section{THE "STRAWMAN" DOPPELGaNGER}

The "Strawman," a third example of Otherlaw, is in many senses the most difficult to understand and explain. The "Strawman" revolves on a concept without precedent in law: an individual has two separate parts, a physical human versus a non-corporeal "legal person" or "Strawman," and that the latter can be split away from the former. The "Strawman" motif is wildly popular in OPCA communities worldwide. In Canada, every identified active guru employs some form of "Strawman" theory or concepts. ${ }^{159}$ This is puzzling because courts uniformly reject the "Strawman" duality, and the "Strawman" has absolutely no historical antecedent.

The "Strawman's" evolution and spread cannot be explained simply by its purported function. Understanding the "Strawman" requires investigation of how those in OPCA communities think, and the unusual manner in which they investigate and frame their world.

\section{WHAT IS THE "STRAWMAN"?}

The "Strawman" concept has undergone some evolution, exhibits variations in its language and explanation, but has a number of constant elements. The "Strawman" is identified by an all uppercase letter name. The two aspects of the duality are allegedly subject to different kinds of law. The "Strawman" legal person is subject to the law typically applied by courts, but the physical human component is only subject to a different kind of law, usually called "common law" or "natural law." A human is not born with a "Strawman," and instead the two are linked by birth documentation which is both a concealed contract with the government, and a kind of stock certificate or security. Governments obtain 
jurisdiction over a physical human through the "birth bond" contract, however that contract can be rescinded or otherwise negated with the correct steps.

"Strawman" theory thus promises a mechanism to escape court and state jurisdiction. Get rid of the "Strawman," and you are free to do what you want.

\section{US “STRAWMAN" NARRATIVES}

The "Strawman" is a comparatively late innovation in US OPCA theory. Unfortunately, the early evolution of US pseudolaw is poorly documented. Until the 1990s, comparatively little attention was placed on OPCA concepts or theory, and reporting instead focused on the actions of Sovereign Citizens and their precursors. Their underlying beliefs received little consideration, beyond that government authority was illegitimate. This limited record handicaps study of the historical evolution of OPCA concepts in that jurisdiction. Few written OPCA texts or guides were apparently created or have survived from this period. ${ }^{160}$ Instead much instruction was through seminars and recorded video materials. ${ }^{161}$ Certain Sovereign Citizen pseudolegal concepts appear to date to depression-era financial conspiracies, and even into the $1800 \mathrm{~s}$. $^{162}$

Fortunately, several early investigators used primary OPCA community source materials, or monitored the racist precursors of the Sovereign Citizen movement. ${ }^{163}$ Their reports outline the development of US OPCA theories. The first US pseudolaw combined a conspiratorial narrative of hidden history with actual legal and historical documentation. This history-based approach to pseudolaw is not universal among OPCA movements. Freemen typically follow a "make it up as you go" approach to pseudolaw, and use language games rather than engage in historical and document-based research.

The Titles of Nobility Amendment is an excellent illustration of how Sovereign Citizen concepts link to actual history. ${ }^{164}$ This "lost 13th Amendment" stripped US citizens of that status if they accepted a foreign noble title. There is an actual 1810 Constitutional amendment that was approved by Congress, but did not become a part of the US Constitution as it fell just short of the required state ratifications. The amendment was, nevertheless, incorrectly added to certain legal texts. Sovereign Citizen theory argues that the amendment was ratified, pointing to these documentary sources, and claim the "real" 13th Amendment removes US citizenship from lawyers, while using the title "Esquire." This is pseudolaw drawn from tangible, though obscure sources.

For example, Koniak, "Law Risks," supra note 7 at n 32 references what she calls the "Ohio Handbook," which does not appear be publically available. JM Berger, "Without Prejudice: What Sovereign Citizens Believe" (Washington: George Washington University Program on Extremism, 2016), online: Center for Cyber \& Homeland Security <https://cchs.gwu.edu/sites/cchs.gwu.edu/files/downloads/Occasional $\% 20$ Paper Berger.pdf $>$ observes at 6, 13 that investigation of the pre-Internet precursors of the modern Sovereign Citizen movement leads to "an incomplete [record] contained in ephemeral small-press publications and pamphlets." Sullivan, supra note 7 at 818 stresses the small-scale and informal character of these publications.

161 Chuck Erickson et al, The Anti-Government Movement Guidebook (Williamsburg: National Center for State Courts, 1999) at 14-16.

See Berger, supra note 160 at $7-13$ for a preliminary but very interesting review.

Koniak, "Law Risks," supra note 7 at n 24; Erickson et al, supra note 161.

Jol A Silversmith, "The "Missing Thirteenth Amendment': Constitutional Nonsense and Titles of Nobility" (1999) 8 S Cal Interdisciplinary LJ 577. 
Early US pseudolaw distinguishes between two kinds of law. The first is "common law," a complete and separate legal system described as a form of Christian natural law derived from traditional English common law. "Common law" is allegedly defined by texts such as William Blackstone's Commentaries on the Laws of England ${ }^{166}$ and Bouvier's Law Dictionary. ${ }^{167}$ The newly formed US was purportedly only governed by this "common law." What followed was a conspiracy by sinister actors — some public, some hidden — who over the next several centuries schemed to strip away the "common law" liberties obtained during the American War of Independence, and enshrined in the US 1776 Declaration of Independence, 1777 Articles of Confederation, and 1787 Constitution.

The 1868 14th Amendment is the critical step in this process. Conventionally, this amendment completed the emancipation process and made all individuals in the US, including former slaves, full citizens of that nation. However, Sovereign Citizen theorists concluded that the 14th Amendment created an entirely new category of individuals, US citizens, and displaced pre-existing "common law" state-based citizenship. ${ }^{168}$ 14th Amendment citizens are allegedly subject to another kind of law, which is variously identified as Roman civil law, admiralty law, martial law, or commercial law. ${ }^{169}$ 14th Amendment citizen status is supposedly voluntary, and the result of a contract that makes property rights subject to the US Federal Government and its institutions. ${ }^{170}$

Sovereign Citizens attempt to revoke the 14th Amendment Citizen contract, renounce Federal citizenship, and restore state-based citizenship via a "quiet title" application where the property is pre-14th Amendment "common law" state citizen status. ${ }^{171}$ This step allegedly frees Sovereign Citizens from Federal authority, including taxes and property obligations in general, and leaves them only subject to supervision by "common law courts," which soon emerged as separate, vigilante entities. ${ }^{172}$

By the 1990s the "Strawman" concept had yet to emerge, but there were elements of its scheme. As government obtains control via a concealed contract, breaking that contract restores a person's liberty to live under "common law." There are ill-focused expressions of a duality that distinguishes between humans and "personas." 173 Uppercase letter names are rejected as they are not a "Christian name."

Vaché \& DeForrest, supra note 7 at 600-607; Robert C Black, “'Constitutionalism': The White Man's Ghost Dance" (1998) 31 John Marshall L Rev 513; Koniak, "Law Risks," supra note 7 at 71-77; Erickson et al, supra note 161 at 9-14, 40-41; Berger, supra note 154 at 4; Koniak, "Chosen People," supra note 7 at 1768-82. Black stresses this re-imagining of historic English common law is, at best, a romantic fantasy.

William Blackstone, Commentaries on the Laws of England (Oxford: Clarendon Press, 1765-1769). Typically, this is the 1856 6th edition. See Mary Whisner, "Bouvier's, Black's, and Tinkerbell” (2000) 92:1 Law Libr J 99.

Koniak, "Law Risks," supra note 7 at 81-83; Sullivan, supra note 7 at 797-98; Harris, supra note 7 at 294-97.

Erickson et al, supra note 161 at 9-12; Koniak, "Law Risks," ibid at 83-86, 89-90; Sullivan, ibid at 804-807.

Erickson et al, ibid at 9-12; Berger, supra note 160 at 3-4; Sullivan, ibid at 801-804.

Erickson, et al, ibid at 34-35; Koniak, "Law Risks," supra note 7 at 68; Berger, ibid at 5-6; Sullivan, ibid at $809-11$.

Erickson et al, ibid at 22-25; Koniak, "Law Risks," ibid at 93-97; Sullivan, ibid at 792-95; Harris, supra note 7 at $287-92$.

Sullivan, ibid at 803 .

Erickson et al, supra note 161 at 47-48, 119. 
The "Strawman" proper first emerged around 1999 as a component of the "Redemption Process." This concept is usually attributed to white supremacist turned OPCA guru Roger Elvick. ${ }^{175}$ Redemption, now more commonly called "Accept For Value" or "A4V," spread like wildfire though the Sovereign Citizen community. ${ }^{176}$ Redemption combined many preexisting Sovereign Citizen motifs and myths within an overarching narrative. The US had gone bankrupt when it abandoned the gold standard. After abandoning the gold standard, the US secured its currency by registering as collateral post-1936 Social Security Act birth certificates, which represent the work value of its citizens. ${ }^{177}$ These "birth bonds" are then sold on the open market. However, the "birth bonds" are not linked to the physical person, but instead to a non-corporeal doppelganger, the "Strawman" "Trust-corporation," which is identified by an all capital letter name.

Elvick taught that the proper combination of Uniform Commercial Code paperwork directed to the US Secretary of State and Secretary of the Treasury permits an individual to seize control of the "Strawman" and its "birth bond" bank account. Other paperwork draws payments from the "Strawman" account. The net effect is a source of free money, though Elvick taught that practically any obligation, including criminal charges, could be "paid" in this manner. Another advantage of the "Strawman" was that governments and laws only (allegedly) apply to the "Strawman," and not the associated physical human.

The problem with Redemption theory is, naturally enough, that it never works. Nevertheless, a succession of gurus continue to teach variations and derivatives of the original concept. ${ }^{178}$

The US version of the "Strawman" has absolutely no independent evidence for its existence. For example, numerous attempts to identify securities or bank accounts linked to Social Security Numbers or birth documentation have proven fruitless. While the "Strawman" was originally integrated into Redemption theory, it has since become a freestanding US OPCA concept, which is in a sense unsurprising since it neatly ties together a number of pre-existing pseudolegal motifs. In this sense, the "Strawman" is a second-order Poverty Law Center, "His 'Straw Man' Free, a Scammer Finds the Rest of Him Isn't”" (27 July 2005) The Intelligence Report, online: $<\mathrm{https}$ ://www.splcenter.org/get-informed/intelligence-report/browse-allissues/2005/summer/patriots-for-profit>.

176 A detailed account of the emerging Redemption phenomenon is found in a 1999 "blog" posting by Mark Pitcavage that was originally hosted on The Militia Watchdog website: Mark Pitcavage, "Old Wine, New Bottles: Paper Terrorism, Paper Scams and Paper 'Redemption"” (8 November 1999) The Militia Watchdog (blog), online: <https://web.archive.org/web/20160516210005/http://archive.adl.org/mwd/ redemption.html>. An archived contemporaneous "Freedomdomain.com" website provides a good "view from the other side of the hill" which clearly illustrates the great excitement which surrounded the Redemption concept, online: $<$ https://web.archive.org/web/20071012185439/http://freedomdomain. com/redemption 1.html>. These two resources are the primary source for this article's summary of Redemption. Certain commentators appear to suggest Elvick promoted his Redemption concept at an earlier point (for example, Berger, supra note 160 at 6,11 ), however, the contemporaneous sources referenced above indicate the Redemption concept dates to around 1999.

177 Koniak, "Law Risks," supra note 7 at 79-81 observes how Sovereign Citizen perspectives of this tumultuous period are orthodox and not much different from those of mainstream legal scholars.

178 While certain gurus keep their variations private, the most common publicly available source for Redemption theory is a text titled the Redemption Manual, which has been published in many versions. The original, The Redemption Manual: A Step-By-Step Guide to Reclaiming your Personal... FREEDOM! [Redemption Manual 1], is undated, and was apparently written by a Rice McLeod. This text has been reprinted and expanded on multiple occasions. The most "current" variation is a fourvolume set: Redemption Manual 5, supra note 29. 
of pseudolaw. It has no foundation beyond the original Sovereign Citizen mythos, that itself builds off a distorted alternative history, and obsolete and marginal legal and historical resources. ${ }^{179}$

\section{THE CANADIAN "STRAWMAN"}

Canada acquired the "Strawman" in two ways: a rather awkward variant advanced by certain Detaxer gurus, ${ }^{180}$ but also a "localized" form created by Freeman-on-the-Land guru Robert Arthur Menard. ${ }^{181}$ Since the Detaxer version is basically the same as the US form there is no need to examine it in any detail.

However, the Freeman version of the "Strawman" is more interesting. Menard's variation does not really change the underlying concept of the Sovereign Citizen "Strawman," but replaces its surrounding conspiratorial narrative with one that makes (somewhat) more sense in a Canadian context. The Sovereign Citizen distinction between "common law" state citizens and 14th Amendment citizens obviously has no application in Canada. Menard therefore reframed the "Strawman" by making all Canadians inherently only subject to "common law." 182

A human being is not a person. ${ }^{183}$ All Canadians are (allegedly) "shackled" to their "person" "Strawman" via a birth certificate, which supposedly is a valuable security that documents a contract between the human and Canadian governments, which are allegedly corporations. ${ }^{184}$ This arrangement is often described as "I am not a person, but I have a person." Government actors enforce legislation via the birth document contract conduit. ${ }^{185}$ Menard recommends parents should not document their children. The result is an individual totally outside government authority. ${ }^{186}$

The Moorish "Strawman" variation is similar, which is unsurprising since it was derived from Sovereign Citizen sources: Dew, "Moors Know," supra note 5 at 79-83.

180 Netolitzky, "OPCA History," supra note 6 at 617-18.

181 Ibid at 624-27.

182 This "mutant" common law is very similar to the US Sovereign Citizen variation: Meads, supra note 8 at paras 326-27; Fearn, supra note 11 at paras 46-64.

183 Robert Arthur, Your Child Or Her Life! Deception And Evil In The Ministry of Children, Family and Community Development (Elizabeth Anne Elaine Society) at 11 [Menard, Your Child]; Robert Arthur, Registration, Application and Submission Means: Drop'em, Bend Over \& Don't Expect Lube: How The Government REALLY Gains Power (self-published, undated) at 49-52, 55-56, 59-61 [Menard, Registration].

184 Robert Arthur Menard, Parking Tickets: The Scam Revealed! (Elizabeth Anne Elaine Society, 2004) at 13, 16 [Menard, Parking Tickets]. In Menard, Registration, ibid at 59-61 Menard analogizes the "Strawman" as a raincoat worn over a child. Robert Arthur Menard, 13 Things The Government Doesn't Want You To Know (Vancouver: Elizabeth Anne Elaine Society and POOPIE!, 2003) [Menard, 13 Things] has separate processes to reject legislation (ibid at 15-16), deny a legal person and physical human are the same (ibid at 17), and reject state authority by denying consent (ibid at 19-20).

185 Menard, Your Child, supra note 183 at 12 and Menard, 13 Things, ibid at 13 use a different explanation. Registering a child abandons ownership of the child, who can then be seized "under the laws of maritime salvage and it becomes their chattel property." In this variant the "legal entity" is the Record of Live Birth document, which is exchanged for a birth certificate.

186 Menard, Registration, supra note 183 at 59-61, 69-72. The text of a "brochure" Menard reportedly distributed to pregnant women (online: Timebomb2000 <www.timebomb2000.com/vb/showthread. php?17105-Registering-your-kids-Brochure >) is reproduced at Elizabeth Anne Elaine Society, online: $<$ www.angelfire.com/rebellion/elizabeth/you_are_not_obligated_nor_requir.html $>$. 
The solution for those who are already "shackled" is to unilaterally withdraw from the birth certificate contract with a document titled a Notice of Understanding Intent and Claim of Right (NOUICR), which restates the principles that are the theoretical basis for the "Strawman" contract, that the Freeman has "opted out," and that the state actor(s) who receive the NOUICR are obliged to rebut it. Otherwise the NOUICR is deemed accepted and in force. ${ }^{187}$ The NOUICR is not only a shield, but also a sword, as its content re-affirms the Freeman can access and demand normal social services and benefits, but also extraordinary ones obtained via a "notary protest" Three/Five Letters procedure. ${ }^{188}$ This breach of social contract earned the Freemen an unflattering nickname: "Freeloaders-on-the-Land."189

Here there is a marked difference from the Sovereign Citizen "Strawman." While that construct is built off a peculiar foundation of legal misinterpretation and historical conspiracy, Menard offers practically nothing to substantiate his Canadian variation on the "Strawman." Instead, he focuses on text found on birth certificates, such as "Canadian BANK NOTE Company Limited" in fine print. However, that is simply the name of a printing company that manufactures blank birth certificate forms, lottery tickets, coupons, share certificates, and other similar items. ${ }^{190}$

A much more suggestive fact is that older British Columbia birth certificates display on their backs "Revenue Receipt No. [number][M/F] For Treasury use only." This notation, allegedly, demonstrates that the birth certificate is more than a simple identification document. ${ }^{191}$ However, again this text has a mundane explanation. Birth certificates have an associated fee, the number is simply used for audit and inventory tracking, and the "Revenue Receipt" and "Treasury" text relates to what is now called the "Ministry of Finance." "192 In any case, text of this kind is certainly not a uniform feature of Canadian birth certificates, and presumably a person who was so unlucky to have been enslaved in this manner could simply destroy their old birth certificate, and obtain a new one which is not a "Revenue Receipt."

The other evidence to back up the Canadian "Strawman" is that Dun \& Bradstreet identify Canada and its provinces as corporations. ${ }^{193}$ This fact is irrelevant because Dun \& Bradstreet

Again, Menard, Your Child, supra note 183 at 13 provides a different solution. Giving a government actor a birth certificate returns the "Strawman," leaving the child free from state authority.

Netolitzky, "Attack," supra note 18 at 150-56.

Netolitzky, "OPCA History," supra note 6 at 639.

See online: Canadian Bank Note Company $<$ https://www.cbnco.com/ $>$.

Menard, Parking Tickets, supra note 184 at $13,16$.

However, this explanation is not necessarily accepted. See "The Government Letters pt. 1" Reflections from the Brave New World (blog), online: <https://web.archive.org/web/20161022032229/http://new notesfromtheunderground.com/the-government-letters-pt-1/>.

Dun \& Bradstreet (online: $<$ www.dnb.com $>$ ) is a New Jersey based private corporation which provides business, sales, payment, debt, and analytics information for many private and public organizations for credit-rating purposes. Its "Business Information Reports" are commonly used to evaluate the transaction history and outstanding debts of a corporation or government organization. The manner in which information is indexed in Business Information Reports leads to unusual data for public organizations. For example, a 2012 Dun \& Bradstreet Report for the Supreme Court of the United States, online: <https://www.scribd.com/document/96516916/Secured-Part-Creditor-for-UNITED-STATESOF-THE-SUPREME-COURT-BUSINESS-Information-Report-2012>, calls the judges and some Court staff "Officer(s)," identifies other courts as "Subsidiaries" within its "Corporate Family," while the Court's description says the organization is a "Subsidiary of GOVERNMENT OF THE UNITED STATES, WASHINGTON, DC." Nevertheless, a full reading of this report clearly shows Dun \& Bradstreet identifies the Court as a branch of government that is authorized by the US Constitution and legislation. A claim that Dun and Bradstreet confirms the Supreme Court of the United States as a business corporation is a wilful misreading of the substance of the report as a whole. 
has, for whatever reason, not created a separate category for government bodies and simply lumps those together with genuine corporations. The second and fundamental defect is why would a "third party, non-Canadian credit-rating database operated by a private US corporation" somehow dictate "the fundamental character of an independent sovereign state"? ${ }^{194}$

While the Sovereign Citizen "Strawman" is at least in some way built off a kind of foundation, the Canadian variation is all but conjured from thin air. Worse, on a theoretical basis, eliminating your "legal aspect" would not logically result in personal freedom from state action, but instead arguably would have the opposite effect. UK traditional common law recognizes humans who have no "legal personage" - slaves. ${ }^{195}$ This result is perhaps the greatest irony of the Freeman "Strawman" concept. By its own rules it ends up removing personal rights and freedoms, rather than the alleged intended effect.

\section{Parallels to Spiritual AND Demonic Possession}

If the "Strawman" concept has no real basis in fact, never works, and is, instead, fundamentally illogical, then why are OPCA communities so powerfully attracted to it? The alleged benefits are tempting, but other less convoluted or tortured pseudolegal concepts such as the original Sovereign Citizen quiet title concept, the Detaxers' defective Coronation Oath scheme, ${ }^{196}$ and the highly adaptable "silence means consent" motif have promised comparable results.

Perhaps more is at play. Perhaps the "Strawman" narrative holds a special attraction not just for the anticipated result, but by how its mythos weaves a narrative of hidden, deceptive control, and that taps into something deeper. There is indeed a parallel to the "Strawman" which is all but universal in human mythology: spiritual and demonic possession.

Possession and exorcism are a widespread and diverse form of human religious belief and experience ${ }^{197}$ which mimics mental illness. ${ }^{198}$ Modern reflections of this form of supernatural control are found in religion and popular culture. ${ }^{199}$ Janice Boddy places possession in a key social location, "about morality, kinship, ethnicity, history, and social memory-the touchstones of social existence." 200 Neuroscientist Patrick McNamara identifies possession as an aspect of a key evolutionary adaptation, theory of mind modelling of foreign

Fearn, supra note 11 at para 69. The corporate registry motif also appears in Australian "Strawman" cases: O'Connell $v$ The State of Western Australia, [2012] WASCA 96 at paras 88, 93; Palmer v City of Gosnells, [2013] WASC 446 at paras 107-108; Hedley v Spivey, [2011] WASC 325 at para 5; Hedley v Spivey, [2012] WASCA 116 at para 6; Lacey v Earle, [2014] ACTSC 397 at para 11.

Reviewed in Pomerleau, supra note 11 at paras 89-95. See also Re Gauthier, supra note 31 at para 55. See e.g. $R v$ Lindsay, 2011 BCCA 99, 302 BCAC 76.

Janice Boddy, "Spirit Possession Revisited: Beyond Instrumentality" (1994) 23 Annual Rev Anthropology 407 at 407-10; Patrick McNamara, Spirit Possession and Exorcism: History, Psychology, and Neurobiology, vol 1 (Santa Barbara: Praeger, 2011) at 2-5 [McNamara, vol 1].

Patrick McNamara, Spirit Possession and Exorcism: History, Psychology, and Neurobiology, vol 2 (Santa Barbara: Praeger, 2011) at 2 [McNamara, vol 2]. Note that this parallels how forensic psychiatrists have evaluated expression of OPCA beliefs: see supra note 16.

IM Lewis, Ecstatic Religion: A Study of Shamanism and Spirit Possession, 3rd ed (London: Routledge, 2003) at ix-x observes possession has "returned with a bang" through multiple personality disorder, alien abduction, and New Age beliefs. Boddy, supra note 197 at 427 identifies a parallel overlap. Boddy, ibid at 427. 
perspectives, ${ }^{201}$ which serves to capture, publically display, and then destroy impure and incorrect behaviour. ${ }^{202}$

Anthropologist Ioan Lewis organizes possession cults into two subtypes: peripheral versus central. ${ }^{203}$ In the latter, leaders experience possession. Peripheral cults involve mass possession. Peripheral possession cults predictably occur in subpopulations that are or are perceived to be disenfranchised or marginalized. ${ }^{204}$ Peripheral cults seek to restore equality, but also extract additional social advantage via possession and exorcism. ${ }^{205}$ The "Strawman" has both peripheral possession cult characteristics. Sovereign Citizens and Freemen see themselves as victimized or mistreated by state authority. ${ }^{206}$ The "Strawman" promises not just freedom, but free cash via Redemption. Menard's "Freeloader-on-the-Land" variation demands routine and extraordinary services.

McNamara identifies key patterns in possession and exorcism: a demon is identified by name, expelled, and then captured in articles that are destroyed. ${ }^{207}$ Experiences with mirror or doubled entities, "doppelgangers," are a form of demonic possession. ${ }^{208}$ Objects may contain and release demons into those who touch them. ${ }^{209}$ Possession experiences are a form of mass hysteria to remove negative influences. ${ }^{210}$

The "Strawman" includes motifs common in possession narratives:

- The "Strawman" is the result of a bargain made by your parents with a deceptive evil trickster who achieves clandestine control through an apparently innocent act.

- Once you have a "Strawman" you are controlled, but you do not even know that. You are subject to "invisible contracts."

- The "Strawman" is your dark shadow double who uses your own name and image. You think you are liable for all manner of things, but that is not true. Instead, your dark twin is at fault.

- The "Strawman" can be removed by a procedure. You always have the power to remove your "Strawman," if you know the truth.

McNamara, vol 1, supra note 197 at 6-10.

McNamara, vol 2, supra note 198 at 47, 77.

Lewis, supra note 199.

Ibid at 27-28, 90, 104-109, 171, 182. These cults "express protest by the politically impotent" of both genders, but is "usually, one of hopelessness" (ibid at 27-28). This is a result of "acute pressure" where a population is "marginal or marginalized, and becomes itself peripheral in relation to a wider, overarching political system" (ibid at 182).

Ibid at 114

Harris, supra note 7 concludes that the Sovereign Citizen population is one that is profoundly alienated from modern US society and government, and perceives itself as marginalized, but in reality, is not truly subordinated. Netolitzky, "OPCA History," supra note 6 at 635-36 and Netolitzky, "OPCA in Family Law," supra note 20 at 960-63 also describe the Freeman-on-the-Land population as separate and threatened, though in very different ways.

McNamara, vol 1, supra note 197 at 82, 133; McNamara, vol 2, supra note 198 at 77, 100-101, 104. McNamara, vol 2, ibid at 103-104.

Ibid at 103 .

Ibid at 124 . 
- Names are powerful. To exorcise the "Strawman" you must know, but never acknowledge, its secret all capital letter name.

- Physical talismans of "Strawman" possession such as birth certificates or other identification must be returned or destroyed. ${ }^{211}$

- Once your "Strawman" is exorcised you must be eternally vigilant, or the "Strawman" will return via apparently innocent acts. Once again you are subject to "joinder." Re-possession can happen easily: when in court you failed to say "I am here on a special appearance," 12 you stood when told to rise, or you agreed you "understand," because "understand" means "I stand under your authority." Answer or acknowledge the all capital letter name and you are again enslaved.

The "Strawman" was invented in a social community broadly affiliated with Evangelical belief, and was likely influenced by "Deliverance Ministry," a demon-removal tradition that emerged in US Pentecostal, Charismatic, and Evangelical Christian communities in the $1970 \mathrm{~s}$, and peaked in the $1980 \mathrm{~s} .{ }^{213}$ The Evangelical variation of Deliverance, which is closely affiliated with the 1980s satanic ritual abuse moral panic, has striking parallels to the "Strawman." 214 Deliverance demons do not control their host, but instead cause "affliction," many forms of pain, and negative influence. Like the "Strawman" and "common law" citizenship, the underlying Christian character of the afflicted remains unchanged. ${ }^{215}$ To command a demon, its name or identity (for example, a demon of lust) must be correctly "discerned." 216 Like "joinder," Deliverance does not offer permanent protection from

Meads, supra note 8 at para 426; $R$ v Furqan, 2013 NSCA 55, 2013 NSCA 55 (CanLII) at paras 6, 9; McDougall v The Queen, 2008 TCC 383, 2008 TCC 383 (CanLII). A striking example is found in an "Additional Application Response" filed on 24 March 2015 in Royal Bank of Canada v Kocsis, Vancouver VLC-S-H-140061 (BCSC) which attaches images of Kocsis's destroyed passport, driver's licence, credit cards, and citizenship certificate.

$212 R v$ Swallow, 2014 NSPC 65, 2014 NSPC 65 (CanLII) at para 5; $R v$ Wywrot, 2012 CarswellOnt 17410 (Ct J); Banque de Montréal c Bolduc, 2015 QCCQ 2529, 2015 QCCQ 2529 (CanLII) at para 9; $R$ c Kaluza, 2010 QCCQ 3694, 2010 QCCQ 3694 (CanLII) at para 22. This is US legal phraseology which indicates that a party only appears in court to dispute that court's jurisdiction.

213 Michael W Cuneo, American Exorcism: Expelling Demons in the Land of Plenty (New York: Doubleday, 2001) provides a useful overview of this phenomenon. Pentecostalism has a long-standing tradition of spiritual possession (ibid at 88-89), both positive and negative. Many books were published by the Evangelical community on this subject. Neil T Anderson, The Bondage Breaker (Eugene, Or: Harvest House, 1990) and Frank Hammond \& Ida Mae Hammond, Pigs in the Parlor: The Practical Guide to Deliverance (Kirkwood, Cal: Impact Christian Books, 2010) are useful representative references given their very wide publication and influence.

214 Cuneo, ibid at 51-58, 198, 200-12. Neil Anderson claimed to have personally exorcised "Harry," a satanic high priest, and offers many sensational exposés of Satanism's alleged wide-spread though clandestine activities, such as "breeders" who bear children for infant sacrifice (Anderson, ibid at 101). Cuneo, ibid at 96-97, 101-102, 107, 201; Anderson, ibid at 99-100. Hammond \& Hammond, supra note 213 at $9-10$ discusses how this approach is a substantial variation from the norm that Christians are immune to demonic possession. This theological controversy is a factor that marginalized Deliverance ministries.

216 See Cuneo, ibid at 61-62, 107-108, 114-19; Anderson, ibid at 166-73; Hammond \& Hammond, ibid at 37-40. See Hammond \& Hammond, ibid at 96-97, 108, 153-54 for the importance of a demon's name. Complex demonic typologies were developed, for example, as found in Hammond \& Hammond, ibid at 125-31. See also Thomas J Csordas, "Embodiment as a Paradigm for Anthropology" (1990) 18:1 Ethos 5 at $13-15$. 
demons, which easily return and "reafflict," after even momentary inattention. ${ }^{217}$ Physical talismans are potent bases for affliction: they must be removed or destroyed. ${ }^{218}$

The substantial functional difference between "Strawman" and Deliverance theories is that the latter is mediated by outsiders who command and cast out demons, while the authority to remove the "Strawman" is personal (though assisted by instruction from gurus). ${ }^{219}$

In Canada, the "Strawman" concept is also hosted by a population which is strongly attracted to New Age, spiritualist, and paranormal beliefs. Freeman guru "Marcus"220 provides a particularly refined example of the Freeman tendency to frame law in a ceremonial and metaphysical context. He explains court proceedings are a literal necromantic ritual where the call to "All Rise" brings the dead "Strawman" to life as a court participant. ${ }^{221}$ "Marcus" stresses the word "person" derives from "persona," or mask, and goes so far as to make a hand-drawn paper mask to illustrate his dual character. ${ }^{222}$ Masks are a key historical component of possession traditions. ${ }^{223}$ It is likely no coincidence that Marcus's mask caricature sports "devil horns."

Thus, the "Strawman" emerged and continues in cultures where the idea of literal possession by non-human entities is not so exceptional. These pre-existing biases may contribute to the "Strawman's" remarkable popularity: the "Strawman" mythos sets an extraordinary legal fallacy within a familiar and accepted supernatural archetype.

Hammond \& Hammond, ibid at 33-34, 45-51; Anderson, ibid at 171-73, 179-82.

Cuneo, supra note 213 at 215. Hammonds' examples of demon-containing items includes Ouija boards, St. Christopher medals, stuffed toys or images of owls and frogs (these animals are "unclean and abominable. They are types of demon spirits"), and traditional religion fetishes and masks (Hammond \& Hammond, supra note 213 at 123, 131, 158-59). "All such items should be burned or otherwise destroyed," but tainted houses may be "cleansed" (ibid at 158-59). They explain certain activities and ideas, such as yoga, karate, and "cults," "false religions," and "occult" practices, also carry demons (ibid at 34-40,130-31). Anderson, ibid at 245 provides a "Non-Christian Spiritual Experience Inventory" that includes "incubi and succubi (sexual spirits)," and warns of the "destructive power of secular music" because "heavy metal and punk music groups are 'owned' by Satanists" (ibid at 121).

Hammond \& Hammond, ibid at 24-25, 101-103, but at 24-25, 69-71 agrees that "first person exorcism" is possible, though risky. Anderson, ibid at 216-18 recommends a more collaborative approach.

Actual name Wilfred John Emonts. "Marcus" instructs via a website (online: Servant King $<$ servantking.info $>$ ) and Youtube videos (online: $<$ https://www.youtube.com/channel/UCT-uSxMHbk 7192ITE9k177g>). "Marcus" says he was a lawyer who in 2007 "personally died and was disbarred." In fact, Emonts" actual history is much more colourful. He was an expert falconer who operated a large Medieval-styled Ontario facility, the "Falconry Centre," until it was closed for regulatory issues. Emonts has published an account of the Falconry Centre and its fate, online: <https://web.archive.org/ web/20161004165303/http://houseofemonts.info/>. Emonts converted the Centre into a marijuana growop, which has been raided on several occasions ("Marijuana Grow-Op Busted at Falconry Centre in Tottenham" (5 July 2012) Madhunt, online: <www.madhunt.com/marijuana-falcon-centre-2012 0705.html>; Rob Cooper, "Marijuana Grow-op Busted in Near Tottenham" (21 August 2015) CTVNews, online: $<$ https://barrie.ctvnews.ca/marijuana-grow-op-busted-in-near-tottenham-1.2527640>), but Emonts was recently acquitted by a jury of marijuana production charges (Brad Pritchard, "ExFalconer from Tottenham Found Not Guilty on Drug Charges," (11 November 2017) Alliston Herald, online: $<$ https://www.simcoe.com/news-story/7880423-ex-falconer-from-tottenham-found-not-guiltyon-drug-charges/ $>$ ).

See “Marcus," Study Notes for Servant King 'Confusion' Videos (undated) at 45-53, 73.

"Marcus," ibid at 49-50; Servant King, "Unraveled: 11 of 14 - Your Personal "Mark of the Beast"” (2 December 2015), online: $<$ https://www.youtube.com/watch?v=jTBG0amI4VM>. McNamara, vol 1, supra note 190 at 28-45. 


\section{IMPLICATIONS}

What does the popularity and use of Otherlaw tell us? Beyond the simple fact that some OPCA affiliates have a profoundly unconventional view on how law works, does Otherlaw help those in government and the courts better understand how to manage the OPCA phenomenon? Again, the answer is not so simple.

\section{A. Belief in OTHERLAW IS Not UNIVERSAL}

A first critical point is that belief in Otherlaw is not universal in the Canadian OPCA community. The "Strawman" is an excellent illustration of this fact. Even though that motif is nearly always a component of what is taught by OPCA gurus, the "Strawman" myth is definitely not universally believed by OPCA litigants. However, that absence of belief does not necessarily mean a concept or methodology is not employed. Some OPCA litigants have no interest in pseudolegal theory, plausible or not. Results are their only concern.

The OPCA litigant population can be divided into three functional subtypes: Accidental OPCA Litigants, Mercenary OPCA Litigants, and Fighters and Believers. ${ }^{224}$ Accidental OPCA litigants are unaware that OPCA concepts are pseudolaw. ${ }^{225}$ The latter two subtypes are distinguished by why they adopt and apply pseudolaw. Mercenary OPCA Litigants are only interested in results, but Fighters and Believers are motivated by both anticipated benefits and the mythos in which OPCA concepts are set.

Mercenary OPCA Litigants sometimes perceive Otherlaw as nonsense. The 2007-2009 Fiscal Arbitrators Detaxer scam is a striking illustration. ${ }^{226}$ Fiscal Arbitrators generated tax refunds by claiming extremely large business losses that were the pseudolegal result of a purported contract between a human being and his or her "Strawman." 227 In only one of the many Fiscal Arbitrators cases heard by the Tax Court of Canada has a taxpayer argued the "Strawman" exists. ${ }^{228}$ Instead, the overwhelming majority of appeals only challenge gross negligence penalties. Many taxpayers openly testified the "Strawman" scheme never made sense to them. ${ }^{229}$ They signed up with Fiscal Arbitrators simply out of greed.

One taxpayer discovered his return had been filed on this basis and immediately disavowed the scam to cooperate with the Canada Revenue Agency: "[t]his is garbage. I am a citizen of Canada. I have been paying my taxes for 40 years. This is absolute nonsense. I won't go along with this." 230

However, review of OPCA jurisprudence and investigation of OPCA social communities reveals other OPCA litigants who enthusiastically embrace the "Strawman" and its

Netolitzky, "Attack," supra note 18 at 175-82. Perry, Hofmann \& Scrivens, supra note 6 at 34-44 proposes a more detailed nine-category typology.

This population is rare and transient: Netolitzky, "Attack," supra note 18 at 175-76.

Reviewed in Netolitzky, "Lawyers and OPCA," supra note 12 at IV(A).

Gray v The Queen, 2016 TCC 54, 2016 DTC 1049 at para 5; Mallette v The Queen, 2016 TCC 27, 2016

DTC 1025 at para 5 explain this scheme.

Brown, supra note 22.

See e.g. Daszkiewicz v The Queen, 2016 TCC 44, 2016 DTC 1042 at para 8; Khattar v The Queen, 2015

TCC 338, 2016 DTC 1011 at paras 9-10.

Morrison v The Queen, 2016 TCC 99, 2016 DTC 1074 at 4-5. 
associated conspiratorial narrative. These individuals clearly attempt to implement "Strawman"-based strategies. A common example is when a litigant claims to act as a representative or agent for his or her "Strawman." 231 The resulting theatrics are often absurd. For example, as the Court read an oral judgment which rejected a "Strawman" defence advanced by Freemen Joseph and Catherine Zombori, Joseph Zombori repeatedly interjected after his name: the accused are "not present." 232 Other times the "Strawman" duality will emerge even when it has no rational connection to an action. ${ }^{233}$

Nor do court warnings that the "Strawman" is a myth seem to make any difference. For example, in 2015 Freeman-on-the-Land Adam Christian Gauthier deployed several OPCA arguments to avoid foreclosure, but also insisted that the lawsuit's style of cause be amended so his name was in upper and lower case letters. His concern was an all upper case name meant his "Strawman" was defending the action. ${ }^{234}$ The detailed written judgment that followed clearly explained that not only is the "Strawman" a myth, but that merely invoking the "Strawman" duality is a basis to presume a litigant acts in bad faith. ${ }^{235}$

Yet only a few months later, Gauthier filed a statement of claim against an RCMP officer and two Crown prosecutors, who had allegedly prosecuted Gauthier improperly. Their potential authority was allegedly restricted to his "Strawman." Unsurprisingly, Gauthier's action was stuck out, costs were awarded against him, and Gauthier was declared a vexatious litigant. $^{236}$

This still did not deter Gauthier, who in 2017 tried to file an attack on police seizure of his unlicensed and unregistered motor vehicle. He again advanced "Strawman" arguments. ${ }^{237}$ Gauthier's filings were rejected, and he was made subject to unusually strict court access restrictions. $^{238}$

\section{B. What Makes Otherlaw AcCePtable?}

What distinguishes the Fiscal Arbitrators taxpayers from Freemen-on-the-Land like Gauthier? A number of factors explain these different responses to Otherlaw.

\section{Pseudolaw Infects Pre-Existing Communities}

First, OPCA movements are not actually created and bound together by pseudolaw. Rather, these are pre-existing communities that are "infected" by pseudolegal concepts. ${ }^{239}$ Host communities can be very different. For example, in most senses, the US Sovereign Citizens and Canadian Freemen-on-the-Land have diametrically opposite world views.

231 See Meads, supra note 8 at paras $440-44$.

$232 \quad R v$ Zombori, 2013 BCSC 2461, 111 WCB (2d) 917 at para 2, appeal dismissed as abandoned 2016 BCCA 9, 2016 BCCA 9 (CanLII).

233 See e.g. Rogozinsky, supra note 11, which reports an attempt to clear debts with a Three/Five Letters foisted unilateral agreement scheme, which has no "Strawman" component.

Crossroads, supra note 11 at paras 26, 36-41, 97-100.

Citing Fiander, supra note 11.

Gauthier v Starr, supra note 31.

Re Gauthier, supra note 31 at paras 53-63.

Ibid at paras 76-85.

Netolitzky \& Rooke, supra note 12 at 91-95. 
Sovereign Citizens fixate on perceived government intrusion into domains such as firearms ownership, enforcement and instruction of non-Christian concepts, and encroachment on private property. Freemen-on-the-Land instead focus on environmental and food contamination, police violence, perceived suppression of natural and alternative health products, and marijuana advocacy. What Sovereign Citizens and Freemen do agree on is that government has exceeded its legitimate authority, hidden and malevolent actors are pulling the strings, and bad times are coming, if not already here. ${ }^{240}$

The Freeman and Sovereign Citizen movements are each embedded in much larger populations of persons with similar political and social perspectives. These larger communities provided a fertile ground for pseudolaw to flourish when pseudolaw promises an attractive result, a response to perceived government misconduct, but also tells a narrative that is consistent with the host populations' preconceived biases. The Detaxers expanded then collapsed because their host population was principally interested in results. A pseudolaw infection ${ }^{241}$ is much more persistent in those host populations where the mythos of pseudolaw in itself has appeal.

\section{OTHERLAW IS UNREMARKABLE FOR SOME COMMUNITIES}

However, some populations that host OPCA ideas have another characteristic critical to the emergence and use of Otherlaw: the prevalence and acceptance of conspiratorial beliefs and perspectives. ${ }^{242}$ Political scientist Michael Barkun argues conspiracy and politically extreme thoughts can be divided into two categories. ${ }^{243}$ Traditional conspiracy theory begins with an organizing theme, such as that the Catholic Church represents a secret menace, or that a secret society such as the Illuminati exert broad and concealed influence.

Barkun observes that an entirely new kind of conspiracy culture has emerged in the past several decades, what he calls "improvisational millennialism." 244 An improvisational millennialist conspiracy does not focus on a particular evildoer, but instead on how hidden actors drive an impending crisis that threatens a dramatic shift to a "New World Order."245 While traditional conspiracies seek potentially hidden or suppressed evidence to confirm a conspiracy, improvisational millennialism "is characterized by relentless and seemingly indiscriminate borrowing." ${ }^{246}$ Improvisational millennialism collects and adds existing conspiratorial and marginal beliefs to an ever-growing collage of data that (purportedly) relates to the hidden dark design. Put another way, conventional conspiracy theories focus on a known enemy whose actions are concealed. Improvisational millennialism sees the dark design everywhere, but the directing minds of the impending New World Order remain in the shadows, or are perhaps unknowable, hidden behind layers of proxy actors. ${ }^{247}$

The result is that the apparent left vs right divide is not really much of an obstacle when it comes to sourcing anti-government theory: see Alasdair Spark, "Conjuring Order: The New World Order and Conspiracy Theories of Globalization" in Jane Parish \& Martin Parker, eds, The Age of Anxiety: Conspiracy Theory and the Human Sciences (Oxford: Blackwell, 2001) at 46.

Netolitzky, "OPCA in Family Law," supra note 20 at 994-96.

Harris, supra note 7 at 298-312 conducts a useful review.

Michael Barkun, A Culture of Conspiracy: Apocalyptic Visions in Contemporary America, 2nd ed (Berkeley: University of California Press, 2013) [Barkun, Apocalyptic Visions].

Ibid at xiii.

Ibid at 38 .

Ibid at 18 .

Ibid at 233-34. 
Improvisational millenialist conspiracy cultures identify relevant information by whether it is denied, marginalized, hidden, or suppressed. Barkun calls this "stigmatized knowledge." ${ }^{248}$ Stigmatized knowledge is reliable and relevant because it is commonly rejected. The Internet has supercharged the distribution and "legitimization" of stigmatized knowledge among improvisational millenialist communities, and facilitated "millenarian entrepreneurs" who market these conspiracies. ${ }^{249}$

Certain OPCA movements, and in particular the Sovereign Citizens and Freemen, are clearly improvisational millenialist conspiracy cultures. Barkun specifically identifies the Sovereign Citizens as such, ${ }^{250}$ but if anything the Freeman movement is an even better example, with its broad hostility to practically all established authorities and institutions, its focus on all manner of ecological, health, food, and financial threats, and underlying all that the pseudolegal conspiracy of illegitimate government control mediated via the "Strawman" doppelganger.

Barkun's improvisational millennialism concept explains why some OPCA affiliates are entirely untroubled by the fact that their pseudolaw is grounded on obsolete legal dictionaries and outdated court decisions, uses principles allegedly distilled from religious texts or that are handed down from ill-defined (or unknown) precursors, all of which is taught via "Youtube videos of men scribbling on whiteboards." 251 These sources are reliable because they are marginalized, rejected by legal authorities, amateur, and often incoherent. The same is true for political and social misconceptions found in the broader communities that host pseudolaw. The toxic and mind-control effects of "chemtrails," chemicals clandestinely disseminated in aircraft exhaust, is confirmed by the absence of evidence to support that. Vaccines must cause harm because the medical and scientific establishment says otherwise. Banks create money "out of thin air" because they insist that borrowers pay back their socalled "loans." 252

This zeitgeist is in nearly complete opposition to the way law is supposed to work, and how courts, lawyers, and academics are taught to think. There is little wonder that their response is to call this nonsense, gobbledygook, and word salad.

\section{OPCA Gurus ANd AfFiliates Are Unusual People}

If that were not bad enough, OPCA gurus and affiliates are often very unusual people. What most would classify as unexpected or bizarre is instead commonplace. Psychiatrists have observed that their actions, speech, and belief are so distorted that mental health professionals must exercise caution to avoid misdiagnosing these individuals as delusional. ${ }^{253}$

Ibid at 26-38. Other names for this collection of data are the "Cultic Milieu" (Colin Campbell, "The Cult, the Cultic Milieu and Secularization" in Michael Hill, ed, A Sociological Yearbook of Religion in Britain 5 (London: SCM Press, 1972) 119 at 119) and "Occulture" (Christopher Partridge, The ReEnchantment of the West: Alternative Spiritualties, Sacralization, Popular Culture, and Occulture, vol 1 (London: T\&T Clark International, 2004) at 62-86). Barkun, Apocalyptic Visions, supra note 243 at 20-21. Ibid at $196-98$.

Crossroads, supra note 11 at para 104 . This is a very accurate description of the majority of modern OPCA instruction.

252 See ibid for a general review.

253 Pytyck \& Chaimowitz, supra note 15; Parker, supra note 15. 
Many OPCA gurus are not the kind of persons one would expect to be plausible leaders of many. At Freeman-on-the-Land guru Dean Clifford's final pre-arrest November 2013 seminar in Hamilton, ${ }^{254}$ another OPCA guru, "Kate of Gaia," speech on the benefits of "urine therapy": drinking one's own urine. ${ }^{256}$ This is not to suggest that urine therapy is broadly practiced by Freemen, but rather that this is a population which finds concepts such as urine therapy unexceptional or even attractive. ${ }^{257}$ Advocating urine therapy or other peculiar ideas has not impeded Kate of Gaia's marketplace success. Instead, at present, she is probably the most successful UK guru, and has somehow accumulated funds to direct large-scale advertising campaigns in that country with hundreds of billboards that proclaim:

\section{Legal Name Fraud \\ The Truth}

It's Illegal To Use A Legal Name. ${ }^{258}$

This legal name fraud theory is a variation on the "Strawman" concept where governments own copyright in a legal name. ${ }^{259}$ Kate of Gaia describes the "Strawman" in a uniquely expressive manner: "[w] hen pair-ents (two minds) or payer-rents choose to REGISTER their children, they are LITERALLY trading off the life source of the being that is SUCKED into that body in this reality for the whore of Baby-loans LEGAL NAME dead child, in essence, ADOPTING Satan's child in LLEU of heaven's child." 260

This is not an isolated example. US A4V guru Winston Shrout, ${ }^{261}$ probably the most successful US guru in Sovereign Citizen and Freeman communities, claimed that during a trip to England he met "The Queen of the Fairies," a very powerful shaman, and that together, they stopped time and moved the Prime Meridian to the "Rose Line" in Paris, ${ }^{262}$ as described in The Da Vinci Code. ${ }^{263}$ During the recent conspiracy-oriented "Conspira-Sea" cruise, Shrout explained that he sits on a "galactic roundtable," and influences world

Clifford was arrested by police at the end of the seminar, held without judicial interim release for 16 months, and received a three-year sentence for drugs and weapons charges: $R v$ Dean Clifford (12 January 2016), Winnipeg CR14-01-33786 (Man QB). His post-arrest influence is much reduced. Also known as Canadian Keith Thompson: Netolitzky, "OPCA History," supra note 6 at 641; Netolitzky, "Attack," supra note 18 at 163, n 130.

256 This practice has both a history in Yogic texts but also emerged from naturopathy: Joseph S Atler, Yoga in Modern India: The Body Between Science and Philosophy (Princeton: Princeton University Press, 2004) at 181-210. Both sources are examples of stigmatized knowledge. See e.g. AS (Re), 2014 ABPC 300, 2014 ABPC 300 (CanLII) at paras 35, 39, 70.

Jon Kelly, "The Mystery of the 'Legal Name Fraud' Billboards," (11 June 2016) BBC News Magazine, online: <www.bbc.com/news/magazine-36499750>. The legal name fraud concept is rejected in $R v$ Unger, 2016 ABPC 46, 2016 ABPC 46 (CanLII). See online: $<$ https://web.archive.org/web/20160804221917/https://en.wikipedia.org/wiki/Draft:Legal_ Name_Fraud $>$. Ibid.

Mark Pitcavage, "Winston Shrout: The Rise and Fall of a Sovereign Citizen Guru" (21 March 2016), $A D L$ (blog), online: $<$ https://blog.adl.org/extremism/winston-shrout-the-rise-and-fall-of-a-sovereigncitizen-guru $>$ provides a useful overview of this individual. See also Netolitzky, "OPCA History," supra note 6 at 630 . www.youtube.com/watch?v=fCXakyUDppc>. 
financial markets together with elves, fairies, and fictional New Age figure "St. Germain."264 Shrout was recently convicted of over $\$ 100$ trillion in fraudulent financial instruments and tax evasion. ${ }^{265}$

Then there is David Wynn Miller, who claims he is the King of Hawaii because he turned Hawaii into a verb, to have an IQ of 200, and that he has not aged since he died and was resurrected at age $25 .{ }^{266}$ Video recordings of Miller's seminars defy both description and credulity. $^{267}$

Other OPCA gurus seem motivated by cognitive dissonance that flows from their own actions and the negative consequences. Eldon Warman emerged as a Canadian Detaxer guru after the suicide of his wife during a dispute with the US Internal Revenue Service. ${ }^{268}$ Freeman guru Menard links his descent into pseudolaw to his failed attempts to obtain custody over a child of his partner Megan, a teenaged runaway crack cocaine user. ${ }^{269}$

The "rank and file" of many OPCA movements are also often persons with atypical beliefs. This becomes very apparent when one explores their social space, what has been called the OPCAsphere. ${ }^{270}$ While fantastic or inexplicable to outside observers, Otherlaw is simply not that different from the ordinary beliefs of these persons.

\section{CONCLuSion}

Koniak says law is growing out there. She describes a "strange and doomed" law; more than mere stories, but instead a system of norms that believers indeed follow. ${ }^{271}$ There is a defect in that conclusion. Plausibly Koniak did not recognize that issue because she wrote about a pseudolaw invented by the more systematically disciplined Sovereign Citizen movement, and before the rise of the "Strawman." A defining principle of a system of law is that its application guides behaviour by providing predictable results. This is the point where Koniak's conclusion breaks down.

Anna Merlan, "Conspiracy Cruise Presenter Winston Shrout Indicted on Charges of Making Fake Financial Documents" (17 March 2016) Jezebel, online: <https://jezebel.com/conspiracy-cruisepresenter-winston-shrout-indicted-on-1765464325>; Anna Merlan, "Sail (Far) Away: At Sea with America's Largest Floating Gathering of Conspiracy Theorists" (25 February 2016) Jezebel, online: $<$ https://jezebel.com/sail-far-away-at-sea-with-americas-largest-floating-1760900554>. United States v Shrout, 2017 WL 1240748 (Or Dist Ct).

Mark Potok, "Full Colon Miller" (15 April 2003), Intelligence Report (blog), online: <https://www. splcenter.org/fighting-hate/intelligence-report/2003/full-colon-miller>.

See e.g. pacman packs, "David Wynn Miller Quantum Grammar Seminar September 2012 Full" (14 January 2013), online: <https://www.youtube.com/watch?v=zgcW6Hzn46w>.

Netolitzky, "OPCA History," supra note 6 at 617-18. Warman died on 18 May 2017: online: <www. vikingfuneralservices.ca/fh/obituaries/obituary.cfm?o_id=4244441\&fh_id=14333>.

Menard, Your Child, supra note 183 at 4-8; Menard, Registration, supra note 183 at 4-6, 18-36, 47-49. See also online: Elizabeth Anne Elaine Society <www.angelfire.com/rebellion/elizabeth/>. Menard's explanation for his interrelationship with the child is not entirely clear. Menard consistently indicates Megan was pregnant when he met her, but also seems to argue that parental rights and obligations crystalize at conception, including his rights in relation to the child.

Netolitzky, "OPCA History," supra note 6 at 635-36; Netolitzky \& Rooke, supra note 12 at 11-14; Netolitzky, "OPCA in Family Law," supra note 20 at 961-63.

Koniak, "Law Risks," supra note 7 at 87-89, 106. Koniak observes that the legal function of pseudolaw distinguishes Sovereign Citizens from a purely revolutionary movement. This is a competition between systems (ibid at 104-105). 
In Meads, Associate Chief Justice Rooke described in-court OPCA activities as a "drama that is more akin to a magic spell ritual than an actual legal proceeding." $" 272$ This investigation shows that some OPCA activities are not "akin" to a magical ritual — they are a magical ritual.

This is not a unique observation. Religious scholars Spencer Dew and Catherine Wessinger observe Sovereign Citizen and Moorish belief in the efficacy of their pseudolaw can be interpreted as magic. ${ }^{273}$

Needless to say, this is a profound challenge to how legal professionals conceptualize law and litigation. Law, from their perspective, is a set of rules organized and derived by logic and function. Law is structured and evolves via a hierarchy of precedent. Some pseudolaw can be deciphered and understood as legal error, or as a misinterpretation of legal authorities and concepts, and in that sense it is not "gobbledygook." A systematic response is then possible. For decades, Canadian court decisions have teased apart pseudolaw to locate and untie these knots in language, rules, and reason. Meads collected that work, and it and its successor judgments have simply accelerated that process. ${ }^{274}$ Some academic writing has done the same. ${ }^{275}$ Effective legal and historical criticism has also emerged from Internet forums such as Quatloos! ${ }^{276}$ and in social media.

But Otherlaw is different. Otherlaw operates outside the system of law, logic, and precedent. A man waves handmade totems of power. A court is told to bow low before a greater master when confronted with seals, signs, and stamps. An image of a thing of value is imbued with that value. We have shadowy doppelgangers - to whom does the court speak? The man or the mask?

Sociologist Max Weber identified "disenchantment" as a central characteristic of modern Westernized culture. ${ }^{277}$ Disenchantment is the displacement of sacred and spiritual belief by a complimentary process, rationalization, which uses knowledge and scientific understanding to calculate a preferred outcome. Modern systems of law aim to operate in this manner, ${ }^{278}$ and that is obviously an organizing axis of some areas of law, such as contract theory. Weber identified a system of law as a critical element of the stable class of state authority, "rational-

Meads, supra note 8 at para 80.

Dew, "Moors Know," supra note 5 at 87-91; Wessinger, supra note 4 at 160.

The Servus decision, supra note 11 which dissected and denounced the WeRe Bank is a good example. Objectively, this decision should be little more than a curiosity. Though Servus was only released on 5 November 2015, it was by 18 December 2015 the ninth most accessed 2015 decision in the CanLII database. However, this decision had received no media attention, and instead was only publicly mentioned on three websites and in social media. After release, Servus was very rapidly detected by a community of anti-OPCA activists and critics, and recognized as the leading authority against a growing OPCA scheme, the WeRe Bank. This information was then disseminated into OPCA social media and online communities.

See e.g. Vaché \& DeForrest, supra note 7; DeForrest \& Vaché, supra note 7.

See online: Quatloos! <www.quatloos.com/Q-Forum/index.php>.

Max Weber, The Theory of Social and Economic Organization, translated by AM Henderson \& Talcott Parsons (New York: Oxford University Press, 1947) [Weber, Theory of Organizations].

Opinion is not universal that law truly has been disenchanted. Jessie Allen, "A Theory of Adjudication: Law as Magic" (2008) 41:4 Suffolk UL Rev 773 reviews legal realist criticism of the "reasoned and principled" component to law, but more interestingly, highlights how law retains what could be called procedural magic, such as the performance-like character of court proceedings, ceremonial and other formalities, and the rigid and arguably artificial structure in which language, information, and argument are managed. Allen concludes this enhances the social function of courts, albeit indirectly. The OPCA community certainly identifies magic in court proceedings. 
legal authority," where guidelines are legitimate because they conform to principles of how rules are enacted, operate, and are enforced. ${ }^{279}$ This process, arguably, also restricts the potential range of personal choice into an "iron cage" ${ }^{280}$ of reasoned, rule-based control. ${ }^{281}$ Legal professionals, by the nature of their trade, see the "iron cage" as a necessary norm.

From the Enlightenment onward it seemed science, reason, knowledge, and rationality has been on an inexorable march, and behind that has followed the disenchantment and rationalization of Western society. Weber saw this as a permanent process where magic is displaced, never to return. ${ }^{282}$ The problem is, Weber was likely wrong. Christopher Partridge's convincing documents demonstrate that "re-enchantment" is now underway via the emergence of "New Age" religions, neo-paganism, alternative healing, and belief in the paranormal. ${ }^{283}$ Conspiratorial beliefs, such as those associated with pseudolaw, are another facet of this re-enchantment process. ${ }^{284}$

This point is of strategic importance. The populations that host and adopt Otherlaw are also the groups that exhibit signs of re-enchantment. For these people magic is real, and not just when it comes to law.

How should courts respond? The obvious answer is to reject Otherlaw as invalid, and point to how it grows from a foundation of paranoia, baseless belief, and blind and obstinate faith. That answer is simple, but intellectually unsatisfying. Conventional law is then a bludgeon based on force, and which teaches through conditioning.

However, that is not so fundamentally different from how Canadian law rejects as invalid, immoral, and wrong, what are perhaps honest and sincere beliefs, such as female genital mutilation, ${ }^{285}$ and polygamy and forced marriage. ${ }^{286}$ Honest dissidents may complain their beliefs are ground under the proverbial Orwellian boot, but courts and state actors can justify suppression of certain belief on a democratic basis, and as an expression of fundamental social values.

Otherlaw can be understood or modelled, but the tools to do so and to respond to Otherlaw are not ones familiar to lawyers and judges. Otherlaw matches known and studied categories of ritual behaviour: sympathetic magic, cargo cult mimicry, and possession and exorcism. In many senses, this observation is the good news. Assistance may be available from experts who study these expressions of human culture, such as psychologists, psychiatrists, anthropologists, and sociologists.

See Weber, Theory of Organization, supra note 277 at 131, and more generally, Reinhard Bendix, Max Weber: An Intellectual Portrait (Berkeley: University of California Press, 1977) at 385-423.

The evocative "iron cage" metaphor is more accurately translated as a "casing (or housing) hard as steel," and was therefore, intended to indicate less a prison than a functional structure: Stephen A Kent, "Weber, Goethe, and the Nietzschean Allusion: Capturing the Source of the 'Iron Cage' Metaphor" (1983) 44:4 Sociological Analysis 297 at 300. Max Weber, The Protestant Ethic and the Spirit of Capitalism, translated by Talcott Parsons (New York: Routledge Classics, 2001) at 123. Max Weber, "Politics as a Vocation" in HH Gerth \& C Wright Mills, eds, From Max Weber: Essays in Sociology (New York: Oxford University Press, 1958) 77.

Partridge, supra note 248.

Ibid, vol 1 at $123-26$; ibid, vol 2 at 313-27.

Criminal Code, RSC 1985, c C-46, ss 268(3)-(4).

Ibid, ss 293-293.1; Reference re: Section 293 of the Criminal Code of Canada, 2011 BCSC 1588, 279 CCC (3d) 1; Blackmore v British Columbia (Attorney General), 2016 BCCA 233, 337 CCC (3d) 244. 
Their advice is necessary. We need to know how to talk to these people. Communication is very important, because legal and justified social control of marginal populations risks radicalization of persons who are already predisposed to view state actors and their fellow Canadians as either agents of a dark design, or its willing collaborators. The self-destructive behaviour, and sometimes violence, that follows is sadly familiar. The growing appreciation that Islamic extremism may be better addressed by deradicalization and reintegration is likely equally true for those deeply immersed in OPCA cultures.

That conclusion takes this article as far as it can go. Further investigation, commentary, and analysis requires social sciences expertise. That said, there is one other additional important question. While this article demonstrates some OPCA litigants are "magicians in court," they may not be the only ones. The same may also be true for certain members of the increasingly frequently encountered vexatious litigant population, ${ }^{287}$ and perhaps some other self-represented litigants. ${ }^{288}$ Whether these groups also include "re-enchanted" magicians is, however, a question for future investigation. represented accused in $R v$ Jamieson, 2013 ONCJ 662, 2013 ONCJ 662 (CanLII) refused to recognize Canadian law because of the "Two Row Wampum" treaty. Religious belief is the central factor in $R v$ Little, 2009 NBCA 53, 349 NBR (2d) 54 where the self-represented anti-abortion tax evader claimed "my Father in heaven does not want me to sign and file tax returns" (ibid at para 10). 
[this page is intentionally blank] 